Sonic Scope: New Approaches to Audiovisual Culture

\title{
From Pussy Riot to Maria Peszek: The Re- Articulation of National and Gender Identities in 21st-Century Eastern European Protest Song
} Joanna Zienkiewicz

Published on: Feb 15, 2021

License: Creative Commons Attribution 4.0 International License (CC-BY 4.0). 


\section{ABSTRACT}

From Pussy Riot to Maria Peszek: the Re-Articulation of National and Gender Identities in 21st-Century Eastern European Protest Song

Joanna Zienkiewicz, University of Groningen, Netherlands

Employing multimodal textual analysis and online anthropology/discourse analysis, this article introduces the protest strategies and domestic receptions in the work of a popular Polish protest singer-songwriter Maria Peszek. By comparisons with the previously researched underwhelming domestic receptions of Pussy Riot - a Russian protest band posing similar social critiques - potential prerequisites for effective Eastern European protest songs are explored. I argue that the "effectiveness," by Serge Denisoff and Mark Levine's criteria, of Peszek's protest songs was achieved through careful negotiations between 'radical' and 'popular' within a "Third Space." More specifically: 'self-Othering' while still promoting the peacemaking 'we're all the same' rhetoric; calling for action and pacifistic alleviation; employing shock tactics in her performance; and using a catchy pop sound, all combined in an audiovisual interplay that balanced the words sung. This paradoxical but well-functioning blend, tailor-made for the cultural context it emerged from, allowed Peszek's music and message to become immensely popular within Poland - an effect which Pussy Riot's Western-inspired protest style did not achieve within its own domestic sphere. As such, I suggest that there can be no universal protest, as both its rhetoric and its audiovisual style need to be context-bound, grounded, and emerging locally, especially within 'post-worlds.'

Content warning: This article quotes song lyrics and online comments which have a homophobic, sexist, or anti-Semitic character.

\section{Introduction}

In 2013, at the nineteenth Woodstock Station, the largest free music festival in Poland, hundreds of thousands of young people chanted along with controversial Polish singer-songwriter and actress Maria Peszek's protest songs against nationalism, hate speech, and an essentialist approach to identity. Known for its pacifistic atmosphere of openness and acceptance, Woodstock Station reacted enthusiastically to the messages Peszek promoted; yet, her influence was not limited to this temporal community. The concert was preceded with the impressive popularity of Peszek's third album Jezus Maria Peszek (2012), which reached number one in the album charts, while its titular single reached the top 10 of the weekly Polish public radio charts and counted up to 2 million views on YouTube. ${ }^{1}$ Her 
next album, Karabin (2016) achieved a similar level of popularity and her song lyrics began to be used and repeated during radical, antifascist, anti-war, and feminist protest marches. $\stackrel{2}{2}$ Simultaneously, her protest music has been widely criticised by nationalists, right-wing politicians, the Polish Catholic Church, and conservative media. It was not long before Peszek became known as the "artist you can love or hate, but cannot remain neutral towards." Regardless of the controversies she has stirred, she remains one of the most recognised modern-day protest song artists in Poland, contributing to the public discussion, and negotiating the political views and identity perceptions of many Poles. On social media, the relevance of her music is cited as 'universal' in nearly every laden political moment up to today, while her most recent tour, Sorry Polsko Super Tour 2020, did not lack in ticket sales despite only including her old material. $\underline{4}$ To explore Peszek's mass appeal, I will critically evaluate the multimodal strategies used in her protest music, as well as the responses to them as uncovered through online anthropology. In particular, I focus on four influential music videos, which highlight different stylistic and thematic approaches. This case study serves as an example of popular protest music acquiring, simultaneously, a mass public appeal and relevance for the ongoing Eastern European political debates.

As a point of comparison within the region, I draw on the example of the Pussy Riot "Punk Prayer" affair in Russia. Pussy Riot posited similar sociopolitical critiques to Peszek's, protesting against enforced gender norms, a nationalist (and semiauthoritarian) state, and organised religion's interference in politics. However, their sonic and performative presentation as outcasts, especially within "Punk Prayer," was far more radical and seemed to oppose nearly every aspect of imagined Russianness. As a result, despite their case being "the story the West wanted to hear," Pussy Riot was hardly supported in Russia. $\frac{5}{}$ Although their style of protest may have worked if it happened in the West (considering the support they have received from abroad), in the Russian context, Pussy Riot's stylistics and rhetoric were perceived as foreign, intrusive, and alien, dissociated from the local history and identity. $\underline{6}$

I propose that the lack of domestic support towards Pussy Riot can be blamed on the unbalanced relations between their riot-grrrl-like, West-inspired protest, and the Russian context. Maria Peszek avoids this problem. Her music penetrates the Polish social consciousness through careful negotiations between radical and pacifistic approaches, and shocking and accessible stylistics, thereby affirming and challenging local, national, and gender identities, all within a well-crafted interplay of audiovisual media. As such, she establishes authenticity as a 'genuine' or even 'universal' artist and a relatable Polish woman, enhancing public interest in her non-essentialist retelling of national and gender identities. Hence, the hypothesis of this article poses questions related to the debates on the Western ideas of feminism and intersectionality being applied globally, supporting the argument that there can 
be no universal protest, as both its rhetoric and its audiovisual style need to be context-bound, grounded, and emerging locally.

\section{Theoretical Framework}

In order to account for its diversity, the definition of protest song this article uses is broad.

Summarised by Beate Kutschke, protest song "usually criticizes the existing social conditions by means of pithy lyrics," and/or "demands change and negotiations with ... mostly groups in power."- As she points out, music is an equivocal medium, and as such political music has to clarify its messages by the use of verbal language, recognisable context, or specific musical means that correspond to a political camp. .8 Protest music "as music" and its interplay with the sociopolitical dramaturgy of the protest activity are only beginning to be analysed.

According to Serge Denisoff, protest song functions can be "magnetic" (simple, direct, attentioncatching) or "rhetorical" (complex, pointing out a problem). $\stackrel{9}{ }$ While its forms can cover any genre, the effectiveness of protest songs can be enhanced by employing the "qualities of simplicity, accessibility and [a] focus on lyrics." 10 An early study by Serge Denisoff and Mark Levine questioned the political effectiveness of popular Top Forty protest songs, with their criteria of "effectiveness" including: “(1) the significance of the material to the listener; (2) legibility of the material; and (3) action upon the message after it has been received - supplementation."11 Importantly, protest songs have the potential to become a "central aspect of collective identity formation" - serving to "build solidarity and make protesters feel part of a strong community." $\underline{12}$ However, this impact of protest music relies on audiences attributing authenticity to the artist.

Two classifications of authentication will guide the analysis in this article. Firstly, Allan Moore's three modes of authenticity - which he divided into first person, authenticating the performer; second person, authenticating the audience; and third person, authenticating an absent other - will distinguish the levels of this strategy in chosen protest songs. $\underline{13}$ Additionally, Hans Weisethaunet and Ulf Lindberg's various authenticity conceptualisations - particularly authenticity as self-expression, body, or negation - will be alluded to. $\underline{14}$ Although authenticity is a performed strategic product of a "musical personae" enacted by the performers, as argued by Philip Auslander, it tends to be understood by audiences as real, leading to them to "believe this self-presentation to constitute the performer's identity as a human being"; not only through the lyrics, but also through the sonic, visual, and extramusical material. $\underline{15}$ 
Methods of analysing the interplay between multimedial materials, especially in the age of digitalisation have been introduced, among others, by Carol Vernallis, Michel Chion, and Lori Burns. Exploring the progression of music video since the 1980s in Unruly Media, Vernallis suggested that the "strongest music videos arise from a nexus of evolving audiovisual relations." 16 Some of her suggested analytical points in music video which this article adopts include: technologies, colour, rhythmic subtleties, character and narrative, performance, dance, settings, framing/packing, haptics, intertextuality, "the fragment"/ the hook, and finally, the function of lyrics. 17

This initial framework is expanded by classifications proposed by Andrew Goodwin (illustration/amplification/disjuncture between a song and its video), Burns' analytic foci (discourse/cross-domain intersections/dynamic gestures and engagement), and Chion's cross-media concept of "synchronization points." 18 Although protest song was traditionally marked by a "focus on lyrics," in the new media age and in the work of both Pussy Riot and Peszek, it must be acknowledged that, as Vernallis states, "in music video, words are changed." 19

The protests undertaken by Pussy Riot and Peszek, despite their varying strategies, centre around similar themes: a reaction against essentialism to gender and national identities; and self-expression of Othered identities. When employing concepts proposed by Homi Bhabha, Benedict Anderson, Judith Butler, and Stuart Hall, the multimodal expressions of these themes can be understood as narrative, constructed, performative, and intersectional. For Bhabha, national identity is a process of constant retelling: an "ambivalent construction" with "both progression and regression, political rationality and irrationality in the very genetic code of the nation." 20 In this process, nationalist discourses constantly attempt to "produce the idea of the nation as a continuous narrative of national progress." $\underline{1}$ Others, alternatively, may attempt to denaturalise identities through revisionism. In-between such hegemonic, essential identities and the Other, as Bhabha suggests, lies a Third Space - "the realm of the beyond," a hybrid zone. $\underline{\underline{22}}$ In Imagined Communities, Anderson posits a similar idea of nations as constructions - "imagined because the members will never know most of their fellow-members," and "as a community, because ... the nation is always conceived as a deep, horizontal comradeship." $\underline{23}$ Although Anderson focuses on how imagining can give power to nationalism, he also acknowledges that national identity can be "modelled, adapted and transformed." $\underline{24}$ Such transformations may be bottom-up, as a result of social movements and protest songs. In fact, the idea of "imagined communities" could even be extended to describe other aspects of constructed, collective identities: namely, gender. Judith Butler has famously described gender as constituted through performative acts, in a similar way nationhood too could be performed through symbolism, narratives, behaviors, and audiovisual cues. $\underline{25}$ 
Finally, Stuart Hall's concept of "articulation" can help to understand the intersectional character of identity expressions in the Eastern European context. The concept was described as a complex structure: "the form of the connection that can make a unity of two different elements, under certain conditions." $\underline{26}$ Articulation is hence relevant to understand the establishing of "mainstream," "essentialist" identities in the Eastern European context and to analyse how Pussy Riot and Maria Peszek challenge such narratives through intersectionality, expressed through a similarly complex, ambiguous "swirl" of audiovisual media. $\underline{27}$

\section{Pussy Riot in Putin's Russia}

In February 2012, the Pussy Riot affair began when the band, in bright-coloured balaclavas, performed their "Punk Prayer" in the Orthodox Cathedral of Christ the Savior, "reinvigorating a feminist critique of patriarchy embodied both in church rites and the state politics." $\underline{28}$ Although the protest was interrupted, the videos of the incident surfaced on the Web, and Pussy Riot band members were arrested for "hooliganism motivated by religious hatred." $\underline{29}$ The event initiated many debates both in Russia and globally; the Western world largely reacted in defense of Pussy Riot, calling for their release, which eventually happened in 2016. $\underline{30}$ However, scholars such as Marina Yusupova present quantitative research suggesting that the support for the band members was far less prevalent and far more controversial among Russians themselves: only $11 \%$ of the interviewed Russians experiencing positive feelings towards Pussy Riot, $38 \%$ remaining indifferent, and $51 \%$ negative. $\frac{31}{}$ Despite being supported abroad, their performative articulation of an intersectional "Russian woman" identity has not been embraced by the imagined community which it was directed at. Instead, the Pussy Riot members were seen as inauthentic, complicit in "a Western-orchestrated conspiracy to weaken Russia," rather than politically active members of the community; to date, their protest has not led to mass consciousness transformation within their national context. $\frac{32}{}$ As an internationally-known and well-researched case of Eastern European protest song, the "Punk Prayer" affair serves as a starting point to my argument. 


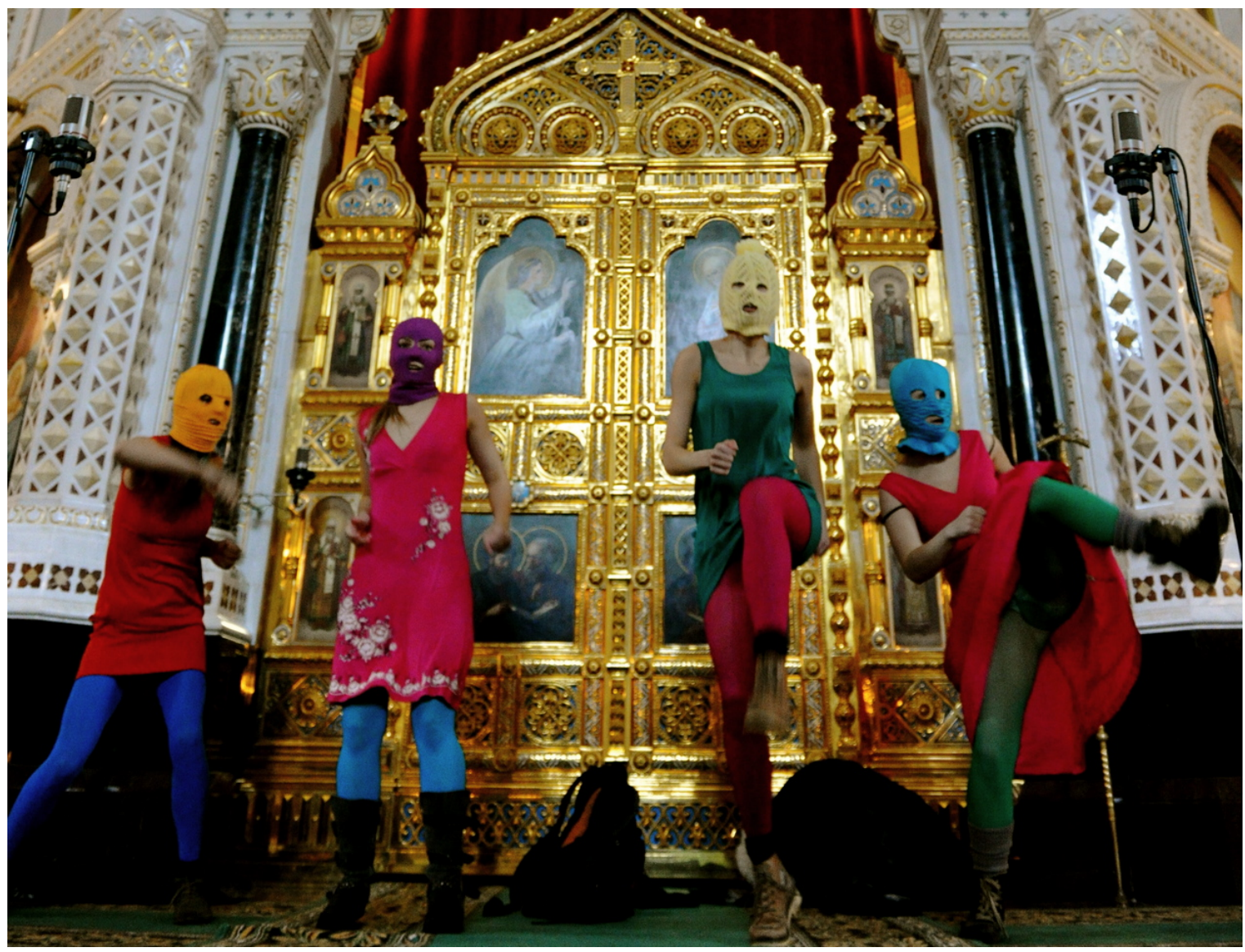

Figure 1. Pussy Riot performing "Punk Prayer" in the Orthodox Cathedral of Christ the Saviour. Photo by Philip Cosores, taken from Michelle Geslani, "Watch: Pussy Riot's historic 'A Punk Prayer' performance on its 2-year anniversary, Consequence of Sound, February 21, 2014, https://consequenceofsound.net/2014/02/watch-pussy-riots-historic-a-punkprayer-performance-on-2-year-anniversary

\section{Context: Post-Soviet Russian Identities}

To allow an in-depth understanding of the conditions that have led to these perceptions of the "Punk Prayer" performance, the context and recent history of Russian national identity and gender relations have to be explored. I mostly focus on the essentialist, Kremlin-centric, state-promoted aspect of the Russian national identity without delving into the ethnic nuances which it is used to suppress.

According to Peter Duncan, contemporary Russian identity is based on the country's imperial - tsarist and communist - history. Historically, the empire has always determined a Russia-wide identification, instead of allowing Russians to "develop a national solidarity amongst themselves." $\underline{3}$ Later on, the USSR promoted a singular Russian national identity based on three elements: "the use of the Russian language, the dominance of ethnic Russians in the leadership, and the sense of the defeat of Nazi Germany as a Russian national victory." $\underline{34}$ Since the collapse of communism, a wider pluralism has begun to evolve, with Vladimir Putin attemping to unify the Soviet and imperial traditions into a modern Russian identity. Ultimately, Duncan distinguishes four Russias that have emerged since the 
1990s and under Putin's direction, based respectively on Soviet memories, pre-Soviet history, Slavic association, and religion (Orthodox Christian). $\underline{35}$ The relation of Russians to the West - "the debates between Westernizers and Slavophiles" - can be another axis on which national identity may become distinguished. Although Putin seeks to cooperate with the West economically, the nationalism of his Russia positions it still firmly outside of the Western influence. $\frac{36}{}$ Similar images of contemporary Russian identity are painted in National Identity in Russian Culture, in which Hubertus Jahn argues that, in modern capitalist Russia, the business of identity, as supported by the state, flourished, and was mostly based upon elements such as the "Great Fatherland War," Slavic folklore, and reemerging (after communist suppression) Orthodox Christianity. $\underline{37}$ Further, Anthony Cross details Russia's Othering of the West as "them," and the emphasis on the Russian language as strong unifying aspects of the "imagined community" in this vast state. $\frac{38}{3}$

One of the similarities between Russia and Poland would be their history of gender struggle, differing from the waves of feminism experienced by the Western world. Due to the Soviet influence, as described by Yusupova, Russia has never went through the second wave of feminism or heard of the Stonewall riots, which proved the importance of direct action and constituted "a pivotal moment in the history of the gay rights movement" for the West. $\underline{39}$

Under the communist regime, the involvement of women in the economy and working equality had been state-controlled; the collapse of the USSR removed the institutional aspect of women having jobs granted and made motherhood a private, rather than public, responsibility. $\underline{40}$ Simultaneously, the resurgence of Orthodox Christianity contributed to the increasingly conservative narratives of gender in post-Soviet Russia, while Oleg Riabov and Tatiana Riabova have argued that Putin's rule and celebrity status have established a sort of neomasculinity model in contemporary Russian society, "attributing masculine characteristics to the country." $\underline{11}$ As a result, studies on Russian youth have shown that they subscribe to rather traditional ideas of performing gender roles. $\frac{42}{I n}$ part, the statesanctioned remasculinisation of Russia was also an attempt to oppose Western influences; through establishing a strong, conservative, Putin-centric masculinity based upon a symbol of Russia as a bear, Russia postulated a masculinity 'better' than the "deviant, feminized, homosexual" masculinity of the West. $\underline{43}$ This remasculinisation further exemplified by a 2012 survey, which found that " $40 \%$ of Russians have never heard the word 'feminism' ... A very small part of the population (8\%) positively relates to feminism." $\underline{44}$ This context is the background for how Russian audiences experienced Pussy Riot's "Punk Prayer" as opposed to Western commentators. 


\section{“Punk Prayer": Analysis}

With "Punk Prayer" accused of "religious hatred" and "hooliganism," one of the key offenses was the chosen setting of the radical performance: the intrusion into an Orthodox religious space. $\underline{45}$ The significance of the cathedral as an impromptu performance space for Pussy Riot's protest has been already explored by Gregory Gan, who argued "Punk Prayer" to be an instance of "subversive affirmation," deterritorialising and disenchanting the setting of the cathedral through retaliating against its imposed habitus. $\underline{46}$ The church itself had a complicated history, paralleling Russia's, and as such was charged with "four Russias" identities beyond the Orthodox Christian identification alone: having assumed various functions - from a palace to a swimming pool - throughout the country's imperial history, it recalled the memories of the tsarist, Soviet, and post-Soviet times. $\frac{47}{}$ Those memories - structuring the Russian identity - have been activated as the "Moscow Patriarchate denounced Pussy Riot's action comparing their assault on the cathedral to the persecution of Jews during the Holocaust." $\underline{48}$ Entering a space sacred but also uniquely Russian, Pussy Riot affirmed parts of its currently accepted habitus: covering their heads (albeit with balaclavas), kneeling, performing the sign of the cross, and singing to a melody based on an Orthodox chanting leitmotif. These affirmative gestures, sonic intertextuality, and lyrical structures (including invocations to Virgin Mary) were synchronised in a reiterated "chorus" of the song; however, a subversive "disjuncture" was introduced through the neon, aggressive colours of the band's dresses, balaclavas, and the rhetorical contents of the prayer -structured lyrics calling a sacred figure to "Banish Putin" and "become a feminist" (see Appendix 1 for full lyrics). $\underline{49}$ According to Sergei Prozorov, this aesthetic of the "Punk Prayer" chorus was one of parody and profanation: the boundary between the sacred and the profane was brought down, resulting in potential blasphemy and leading to interpretations of even the affirmative gestures within the performance as antagonistic or "hateful." 50 "Punk Prayer" verses introduced yet another rift, this time synchronised to subvert the Russian cathedral's and conventional feminine habitus in riot-grrrl-like protest aesthetics: loud, harsh, punk rock sound; electric guitars; shouted lyrics; dissonances; and a mosh-pit-like dance that included punching and kicking next to an altar. These aesthetics amplified the consecutive lines of the song undermining Putin's neomasculinity ("Banish Putin!"), unveiling the Church's corruption in connection to the state ("Patriarch Gundyaev believes in Putin"), and opposing the limited nature of freedom ("Freedom's phantom gone to heaven"), homophobia ("Gay Pride's chained"), the past Soviet alignments of country's current officials ("head of KGB"), or conservative approaches to gender roles ("Stick to making love and babies"). The interplay of audiovisual elements and the lyrics within the "Punk Prayer" cathedral performance firmly positioned it as a radical and stylistically disruptive protest event, with even its affirmative elements suggested to be ironic/blasphemous towards the Orthodox faith, the Russian historical tradition, and 
(state-promoted) modern Russian identity. The masked faces of the band members, obscured from the public's eye during the performance, could only further distance rather than engage the viewer.

According to Illa Yablokov, the vast international popularity Pussy Riot achieved did not help to counter the idea that the band members were a part of an international "plot to weaken Russia." $\underline{1}$ Additionally, the band were accused of being "vulgar, impudent, cynical" women, aligning themselves with the Western Other (feminism, homosexuality, atheism) more than with any of the Russian identity elements. $\frac{52}{}$ As such, despite being Russian, Pussy Riot could be seen as not 'truly' Russian, not part of the pre-established 'nation narrations,' and hence foreign. Given recent Soviet history, many Russians remain particularly sensitive towards anti-religious sentiments and female liberation, as both used to be promoted by the communist regime, and remember the West as a recent enemy, which made Pussy Riot's Western-coded protest an enemy as well. The disruptive audiovisual aesthetics of "Punk Prayer" likely "amplified" the perceptions of Pussy Riot from a distinctive Other to a "threatening, intrusive, and antagonistic" Other that overrode something traditionally Russian with the Western "loud and vulgar" influences. $\underline{53}$

Following this analysis, I will now narrow down diverse strategies of protest song into two broad "rhetorical” categories: 'radical' and 'pacifistic. $\underline{54}$ While radical protest songs - represented by Pussy Riot's "Punk Prayer" - would identify the protesters and their oppressors as antithetic, and call for disruptive action, pacifistic ones would rather promote peaceful unification of all people against a common problem, such as hatred or inequality. These rhetorical categories usually parallel but might also challenge similarly broadly divided 'disruptive' and 'mass appeal' audiovisual/"magnetic" music video styles. $\underline{55}$ As I suggest, protest music has ranged from generally pacifistic/mass appeal to radical/disruptive throughout its global history - from John Lennon to punk rock and riot grrrl movements, both of these types have enjoyed varying levels of success, although nowadays radical protest appears to be more prolific in the Western music world. Such was the protest of Pussy Riot. Rhetorically radical protest songs could employ narratives of resilience against oppression, calls to revolutionary action, or "self-Othering": purposeful positioning of oneself as an outcast, outside of the dominant social group, in order to empower one's marginalised group(s) despite differences. $\underline{56}$ Such protest songs, as in the Pussy Riot case, would usually be combined with disruptive audiovisual stylistics including performative shock tactics: graphic depictions of violence, defamiliarised/uncanny/queered performance, profanation, reclaiming slurs, DIY aesthetics or rough editing of music videos, and sound affectively marking "discontentment, conflict, and anger" as well as strength and empowerment (with harsh timbres, hoarse vocals, dissonances, and agitated rhythms). $\underline{57}$

Much of the audiovisual interplay of disruptive protest songs could be inspired by real-life protests and riots: marking musical personae within the countercultural rebel archetype, identifying enemies 
and oppressors within the hegemonic systems, and primarily authenticating performance through “negation." $\underline{58}$

On the opposite end of the spectrum, rhetorically pacifistic protest songs could promote narratives of universal human identity, collective responsibility for social problems, and strong anti-violence/antihate messages, through appealing to morality, empathy, and imagination. The stylistics of such protest music would often be, to borrow Denisoff's terminology, "magnetic" and mild. $\underline{59}$ Designed to resonate with the masses, such songs' can employ visuals which highlight vulnerability and hope (by including child characters and families, broad shots, juxtaposing utopian and dystopian imagery, symbolism and colours), and in pleasant sounds: often simple, affective melody lines or catchy, soaring pop tunes. While this type of protest song could have a greater potential for mainstream success or, in Denisoff and Levine terms, "significance," radical/disruptive protest songs could be expected to provoke a greater influence on public debates, being more likely to have its material "legible" and "supplemented." $\underline{60}$ It is disputable which type of protest would prove more effective. As such, I will now apply Denisoff and Levine's criteria of effectiveness to Pussy Riot's radical/disruptive protest to later compare these results with Peszek's, who could be assessed as positioned in-between suggested protest strategy extremes.

\section{“Punk Prayer": Assessing Effectiveness}

With the protest song not merely transforming, but outright opposing nearly all elements seen by the Russians as defining their unique, post-Soviet identity, the pejorative associations of Pussy Riot with a "Western conspiracy" were inevitable. $\frac{61}{}$ At best, the alternative identity articulations of the band members were not understood by the state media and many Russians; at worst, they were seen as a betrayal of imagined Russianness. Ultimately, what was meant as a protest by and for Russians became a "story the West wanted to hear" all while being "cynically exploited by Kremlin to advance its neo-traditional values agenda." $\underline{2}$ Instead of resonating with Russians ("authenticating the audience"), the radical protest rhetoric and disruptive, non-magnetic aesthetics which worked in the Western riotgrrrl movements became a dangerous Other in the East. $\underline{63}$ As Yablokov argues, "at least in the short run Putin seems to have benefited more than the opposition." $\underline{64}$ The release of the band members cleared the international controversy while allowing conservative values and identities to surface even more as opposition against the "deviant" Westernizers which Pussy Riot has now become a symbol of. $\frac{65}{}$ Recalling Denisoff and Levine's effectiveness criteria, their protest was then not legible enough (seen as "religious hatred") and its significance to the listeners could be questionable. $\underline{66}$ In the long 
run, this kind of protest could prove ground-breaking through supplementation, inspiring future transformative movements, but, at least for now, Pussy Riot remains listened to mostly in the West.

\section{Maria Peszek in Pis's Poland}

Maria Peszek is a Polish actress, singer, and songwriter with four studio albums released to date. Her music is usually described as "alternative" and, together with her music videos, continues to stir controversy in the Polish public sphere. $\frac{67}{}$ These videos, as will be discussed below, often feature shocking, by Polish standards, visuals (featuring androgynous looks, raw sexuality, music videos often depicting violence) and unfiltered lyrical content (with explicit themes of female sexuality, bold historical parallels, and a rejection of Catholic faith and martyrdom nationalism). In her protest, Peszek challenges gender norms, the ruling party, nationalists, and the Church's involvement in politics, similar to how Pussy Riot did in Russia. Despite similar themes of political criticism, her protest strategies, and transformative articulations of alternative, self-established identities have been welcomed by the Polish imagined community. Retaining a status of a controversial protester, Peszek has reached the top of the Polish album and singles charts multiple times (despite allegedly not being given radio airtime), her music videos have gathered millions of views on YouTube, and her concerts have featured hundreds of thousands of Polish people chanting along to her protest songs, proving their magnetic, mass appeal value. $\underline{68}$ In this article, I will focus mostly on four music videos from Peszek's two most recent albums, Jezus Maria Peszek (2012) and Karabin (2016), both of which achieved success on Polish charts and platinum album statuses. $\underline{69}$ The chosen music videos - "Ludzie Psy” (“Dog People”), “Polska A B C i D” (“Poland A, B, C, and D”), “Ej Maria” (“Ey Maria”), and “Modern Holocaust" - stirred much controversy in the Polish public sphere and exemplify various rhetorical and stylistic directions in which Peszek's social critique branches out. I will first outline the context of the contemporary Polish nationalist mainstream, and later focus on analysing the interplay of media in Peszek's songs, their lyrical rhetoric, and will finally assess their effectiveness through online anthropology.

\section{Context: Post-Communist Polish Identity}

The recent history of Poland was tied closely to the USSR since the end of World War Two: through the era of People's Republic of Poland (PRL), along with the Polish Workers' Party, worked closely with the 
USSR officials until the liberation in 1989. $\underline{70}$ Under communism, Poland went through a similar suppression of Roman Catholic religious identity, dissociation from the Western world "unavailable under a Communist regime," and through feminist developments (state-controlled workplace equality instead of a bottom-up second wave). $\underline{71}$ Throughout the PRL era, Polish artists established a culture of protest songs which managed to avoid censorship through balancing cues of dissent with ambiguous "under-coding," with many of these songs eventually becoming hymns of the "Solidarity" protests in 1989. $\underline{72}$ Afterward, the Polish identity was reshaped.

In her book Reshaping Poland's Community After Communism, Helena Chmielewska-Szlajfer describes three "ordinary celebrations" that were crucial to the formation of the Polish postcommunist imagined community: the celebration of the Roman Catholic religion at sanctuaries; of freedom and mutual recognition at the Woodstock Station festival; and finally, of civic engagement in politics. $\underline{73}$ Polishness, in her words, became "a new social imaginary in which aspirations of 'catching up' with the West are mixed with religious conservatism and the persistence of a national tradition of struggles for a sovereign nation-state." $\underline{4}$ Addressing recent developments, Chmielewska-Szlajfer notes that the influence of the Catholic Church (also on the political sphere) is only increasing and "catching up with the West" is becoming less pronounced: after a shuffle between two major Polish parties, "since 2015, Poland has been ruled by the Law and Justice (PiS) party, which won both presidential and parliamentary elections playing on fears of the West" as "inviting terrorists, imposing gender equality and gay rights." 75 Under the slogan of "good change," PiS has been described as "populist, nationalist, right-wing, EU-skeptic, largely dependent on the opinions of the conservative Polish Catholic Church," and has been criticised for "systematically undermining the rule of law, including the Constitutional Tribunal and the judiciary as a whole" and for their assault on the freedom of national media. $\underline{76}$ Despite this, the party enjoys major domestic support. With the society deeply divided 'for' and 'against' the traditional Polish values PiS represents, little room is left for a Third Space between the hegemony and the Other. Similar to Putin's Russia, those wishing for West-like transformations in the Polish imagined community are often called traitors or "the worse sort of Poles" in the public discourse and by select party officials. $\underline{77}$ The 'essentialist' Polish identity promoted by PiS includes nationalism, conservative Catholicism, and amplification of Polish national martyrdom: a "forcibly patriotic," "masochistic" dominant idea that all Poles should be ready to die for their country, resulting from the long "Polish history of struggles for political independence." $\underline{78}$ In terms of gender developments, the period of social transformation following the collapse of communism found women losing the institutional access to jobs and social benefits, as well as decreasing their political participation. .99 The resurgence of the Catholic Church and PiS's policies are especially criticised for regressing the equality efforts, making conventional gender roles a part of the essentialist Polish identity. In recent years, anti-genderism (anti-challenging gender roles) became a prolific movement, with the "Church's 'STOP GENDER' campaign [that] is unapologetically against equality." $\underline{0}$ Described 
as a threat to traditional Polish families and as a "foreign ideology" by leading politicians (including the Polish president Andrzej Duda), LGBTQ + communities have been stigmatized, and symbolically excluded from "LGBT-free zones" appearing throughout the country. $\underline{81}$ 'Family' in the traditional sense was preached by PiS to be the backbone of their policies, with monthly social benefits for the parents of $2+$ children ("Family 500+"). $\frac{82}{}$ At the same time, since 2016 the Church-influenced attempts of the party to pass an abortion ban sparked "Black Protests" (2016) with women going to the streets throughout the country. $\frac{83}{}$ Further abortion restrictions were recently re-introduced for parliamentary consideration amidst the Covid-19 pandemic: at first, women protested online and from their windows, to eventually begin mass All-Poland Women's Strike street protests when the restrictions passed

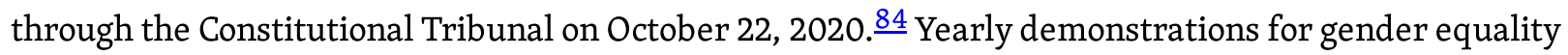
are organized by Manifa, a group of radical feminists. During these protests and the All-Poland Women's Strike, Maria Peszek's song lyrics could be seen on posters and placards carried by protestors. $\frac{85}{}$

\section{Peszek's Music Videos: Analysis}

\section{“Ludzie Psy” (2012)}

The first of Peszek's albums to stir a major controversy was her 2012 LP Jezus Maria Peszek. Although the album was released before Law and Justice's rule, similar debates were present and the aforementioned 'essentialist' Polish identity was already being consolidated. Accompanying the release, Peszek revealed the personal character of the album, describing it as self-expression, a description of her journey through depression, and a voice for outcasts. $\frac{86}{}$ As such, she claimed her "musical personae" to be equal to her as an artist; simultaneously, she stated that "she's not controversial; just open and independent." 87 The album was met with a mixed reception and many controversies that will assessed below. Nonetheless, the release went platinum in Poland, while its two most controversial songs, "Sorry Polsko" and "Ludzie Psy," reached third and seventh respectively on Radio Poland's hit lists. $\underline{88}$

\section{Visit the web version of this article to view interactive content.}


The official music video to the latter of these singles - "Ludzie Psy," the only music video released from the album - was uploaded to YouTube in November 2012 has since surpassed 2 million views, with a 13k/1.3k like-to-dislike ratio. It became one of the first widely popular songs in which Peszek attempted to fulfill her intention of being "a patron of outcasts" and "a basket for dirt and trash: unpleasant, incorrect topics," through a blend of disruptive and mass appeal audiovisual stylistics as

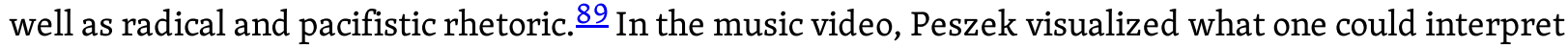
as the violence inherent in the processes of interpellation and Othering. Reminiscent of Marina Abramović's "body-as-text" performance art, Peszek was depicted naked, facing the camera against a backdrop of a barren, gray wall, while her space was infringed upon by a male hand and her body violated: gruesome wounds appear, her body is deformed, tape seals her mouth, foil covers her face, and mud and markers pen mark her body. $\frac{90}{}$ This near-tangible, "haptic" body horror and "dynamic gestures" appeared in glitchy sequences edited precisely, synchronized with a sharp snare signaling the end of the verse in the audio, with their frequency increasing as the song progressed. $\underline{11}$ The video as a whole maintained a rather raw, DIY aesthetic, further amplifying the disturbing experience of watching the video. Despite being mediatised online, this disruptive performance could rival the shock tactics of Pussy Riot in evoking strong reactions from its viewers. Interestingly, however, it was juxtaposed against rather accessible music. Despite the few "points of synchronization," the steady, minimalistic accompaniment can be seen as creating a "disjuncture" with the bold performance - or

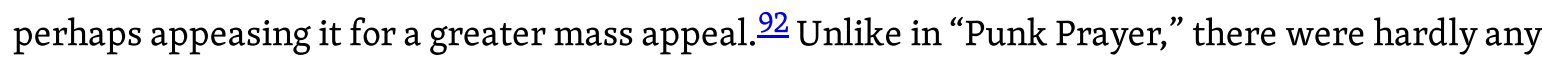
punk rock or similarly radical, agitational genre influences in "Ludzie Psy's" sonic content; as Peszek claims, the sound of her songs (produced by Michał "Fox" Król) was consciously meant to be "simple, boorish, pop, and maximally effective." $\underline{93}$

Highlighting the lyrics, the melody line was mostly carried by the foregrounded emotional, pleasant vocal work, while the instrumentation, which featured electronic and percussive instruments with lofi timbres, was relegated to the role of a rhythmic accompaniment, synchronised with the movements in the music video. Towards the second chorus, the backing track expanded in layering, introducing a catchy and surprisingly uplifting synthesiser-led electronic dance tune. Despite, or rather because of, its pop-ish minimalism, the audio generated mass appeal and made this radical song suitable for top radio charts, a privilege few protest punk songs have experienced. Throughout the song and the video's enacted violence, Peszek's androgynous character - sporting an undercut and earrings - consistently engaged the viewer and displayed an awareness of being watched by gazing directly at the camera. Her expression was rather "undercoded," warranting a variety of interpretations of her gaze - from empathy-provoking to accusatory. $\underline{94}$ The character's relationship to the viewer could, however, be further clarified through analysing the function the lyrics played in increasing the "engagement" of Peszek's audience (see Appendix 2 for full lyrics). $\underline{95}$ Starting from self-expression of personal suffering, the artist began referring directly to the audience through the pre-chorus and chorus. Using 
the pronouns "me" and "you," but also "we" and "us," Peszek delivered litanies of reclaimed insults ("bad side of the nation," "meat of the soul ... porn, mush," "mutts, weirdos, punks, loonies/Degenerate citizens") additionally amplified through visual details of the music video, seen in the writing on her skin stating "meat," "porn," "scar," and "weed" (00:53). As such, branding herself as "queen of trash," Peszek identified her musical persona as a representative of a community of outcasts she addressed in the song lyrics and with her gaze. Instead of a balaclava and a colourful dress, Peszek chose to decrease the distance separating her from the audience and highlight her vulnerability through nudity. In Moore's terms, the interplay of image and text in "Ludzie Psy" authenticated not only its performer but also its clearly defined audience: various types of the Other who remain excluded from an essentialist Polish identity.

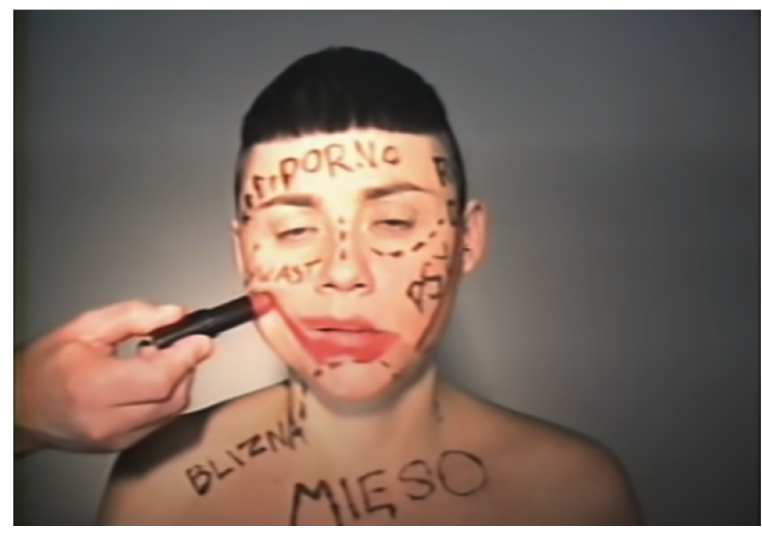

Figure 2. The writing of slurs on Peszek's skin. Screenshot from Maria Peszek, "Ludzie Psy / Official video / Maria Peszek," November 21, 2012, accessed November 24,
2020, https://www.youtube.com/watch? $=$ sfYue0xulcl.
Despite the unquestionable shock value of "Ludzie Psy," the Otherness performed by Peszek was not presented as threatening, intrusive, and antagonistic, further separating it from Pussy Riot's "Punk Prayer." Rather, the visuals of the single showed the oppressed as vulnerable, embodied, human, and suffering at the hands of an unidentified aggressor. Meanwhile, the audio did not detract too much from acceptable radio-friendly conventions, and the lyrics (in the context of the audiovisual interplay) were coded as not pointlessly vulgar but reclaiming. Interestingly, Peszek chose to

"sing" the lyrics on camera in only one moment, hence marking her vaguely phrased call to action for the newfound collective of excluded ("Let's make smoke" as vital. However, even this potentially radical line was not followed up with revolutionary signification. At the end of the video, Peszek sighed: a gesture that could be a sign of misery or resignation but could be understood as victimhood as well. All media considered, the official video of "Ludzie Psy" turned out to be a manifesto directed at unifying the struggles of diverse groups marginalized in post-communist Poland, designing a new collective identity for such groups, as well as authenticating the suffering and violence inherent in Othering processes. The disruptive music video visuals were juxtaposed with a mass appeal, radiofriendly sound; within the lyrics, "words were changed" from a potential revolutionary call to an embodied display that mixed empowerment with an empathy-inducing vulnerability. $\frac{96}{}$ While narrating a new, non-essentialist subcategory of Polishness - one that includes outcasts and the Othered - the song remained undercoded, unlike "Punk Prayer" not recalling any specific axes of marginalisation and not attacking any aspects of Polish identity. As a result of this rhetorical vagueness and performed vulnerability, the protest elements of "Ludzie Psy" appeared mild and 
peaceful even with all its shocking elements - pointing out an issue rather than threatening anyone. This initial positioning allowed Peszek to further establish the authenticity of her song's message later on, specifically in the "Róbmy Klip" version of the video, where she allowed anonymous online contributors to draw on a randomly chosen frame of the video. Besides expanding the communitybuilding role of "Ludzie Psy," the action's results - a new music video created from the altered frames exposed the discrimination of the Other that Peszek depicted. Among less symbolically charged drawings, one could spot multiple images transforming the artist into Hitler or anti-Semitic stereotypes, and included swastikas, Illuminati symbols, Star of David, or vulgar words in the final product. Through "Róbmy Klip," Peszek's position at the forefront of the community of excluded was authenticated, and the need for her protest against forced Othering further confirmed.

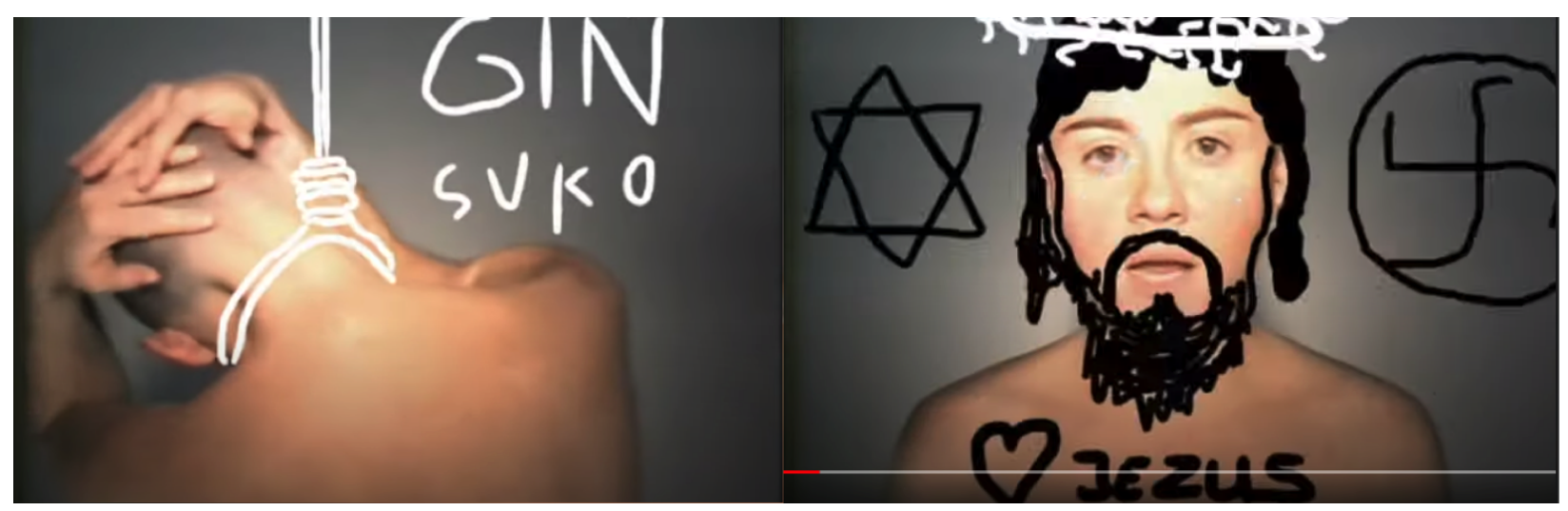

Figure 3. Two screenshots from the "Róbmy Klip" participatory action's final product. Peszek depicted hanged with the caption "Die bitch" and as Jesus with an accompanying Star of David and swastika. Taken from Maria Peszek, "Ludzie Psy / Róbmy Klip / Maria Peszek," January 18, 2014, accessed November 24, 2020, https://www.youtube.com/watch?v=GRF5TrKqLOo.

\section{“Modern Holocaust” (2016)}

Peszek's latest album, Karabin ("Rifle"), was promoted as "an album about hatred, which turned out to be about freedom." 97 Peszek acknowledged the separate character of the release from Jezus Maria Peszek, describing it as "more mature ... a realization of a world beyond her" and "a pacifistic album in military terms." $\underline{98}$ The album was awarded platinum status, with three singles accompanied by music videos leading to much public discussion: "Modern Holocaust," "Ej Maria" and "Polska A B C i D," the latter of which reach number one in the Polish singles chart. $\underline{99}$

\section{Visit the web version of this article to view interactive content.}


"Modern Holocaust" remains controversial due to the comparison it drew between mass genocide and contemporary Othering, and was subjected to critical articles, censorship by iTunes, and removal from the radio charts - albeit still supported online (14k to $8.4 \mathrm{k} \mathrm{like} \mathrm{to} \mathrm{dislike} \mathrm{ratio} \mathrm{on} \mathrm{the} \mathrm{official} \mathrm{music}$ video uploaded to YouTube). $\underline{100}$ The song, as Peszek claimed, was intended to point towards the danger of "the cruelest events in the history of mankind: wars, genocides beginning with words." $\underline{101}$ Released already under Law and Justice rule, "Modern Holocaust" promoted a sense of apocalyptic urgency through its affective, minimalistic music video. Rapidly shifting between portraitshots of a lip-syncing Peszek, and full body shots of the internationally renowned dancer Pawel "Pablo" Krupa, the music video features its performers on an empty floor in front of a wall of flames. Flames and fire formed a central theme of "Modern Holocaust," addressed in lyrics mentioning "the Auschwitz oven," and comparing the contemporary event of Warsaw Rainbow burnings with arson during the 1941 Jedwabne pogrom (see Appendix 3 for full lyrics). As in "Ludzie Psy," Peszek maintained an androgynous look, a front-facing position, and a concerned gaze directed at the viewer throughout the video. This time, however, the engagement of eye contact was not disrupted through glitch depictions of violence, but rather through the highly expressive, aggressive dance of Pablo, often edited in a staccato, single-figure manner (see for example 2:22-2:26). At times, his dynamic gestures and expressions coincided with mentions of violent events in the lyrics, potentially positioning him as a perpetrator. However, synchronising the visuals to the lyrics seemed to be less of a focus than matching the dance to the song's rhythm. The musical side of "Modern Holocaust" was mostly dismissed by reviewers; the song was argued to "go in the lyrical [rhetorical] rather than musical side." $\stackrel{102}{ }$ However, the audio could have had its role to play particularly in amplifying the urgent, apocalyptic affect supposedly resulting from the music video and the pessimistically prophetic lyrics. With a backing track more minimal than on Jezus Maria Peszek - mainly based on lengthy drones played on an old Soviet polivox (its intonation kept imperfect on purpose) - and accompanied by a repetitive drumming pattern, the music remained tense and without resolution. $\underline{103}$ The chorus was only signified by a change from Peszek's near-reciting of the verses to more melody-leading, memorable singing. Throughout the song, her voice frequently 'broke' in higher pitches as a way of authenticating the rawness of the protest, and, once more, the vulnerability of the Othered contrasting with Pussy Riot's disruptive empowerment. This performance of weakness in the face of an apocalypse was specified and amplified through the lyrics. Less ambiguous than the text of "Ludzie Psy," "Modern Holocaust" directly quoted the hate speech that Peszek experienced as an authentication of herself and her oppression - including marginalising her as a "Jewish whore," "leftist scum," "stupid bitch," misrepresenting her as a "dyke," and threatening her to "destroy her, kill her." The artist localised such Othering as a "Polish Modern Holocaust," suggesting it as comparable to traumatic events from Polish history such as World War II, the Holocaust, and the brutality of PRL's secret police (ZOMO), as well as to more contemporary fears such as Putin and Osama Bin Laden. Through these unambiguous lyrics, she performed a knowledge of Polish context and history, 
positioning her protest as having a unique significance to the nation. However, to some, she crossed a line of profanation in the extent of her comparisons, which re-articulated the Polish imagined community as significantly darker than the state-promoted ideas of 'progress' and heroic martyrdom: as one full of problems, polarization, and hatred. .104 As in Pussy Riot's case, it was the concern of such profanation of key local identity aspects that could result in the song being dismissed as foreign and antagonistic. However, this was partially alleviated by mild audiovisual content, the song's serious (rather than ironic) tone, and by its chorus which, unlike "Ludzie Psy," did not set the community of the marginalised apart from the hegemony. The binary was instead deconstructed in a suggestion that all sides of the polarised conflict, including the viewer and Peszek herself, are equally capable of hatred: "Evil is inside all of us ... You too have in your house / Your own rifle." Hence, the rhetorical message of the song's chorus could be interpreted as more pacifistic than radical.

In the entirety of its minimalistic, apocalyptic audiovisual form, "Modern Holocaust" became an urgent, tense, authentic, and deeply concerned warning directed towards any form of radicalism within the Polish imagined community, rather than a revolutionary spectacle. Through minimalistic interplay of disruptive and mass appeal audiovisual strategies, the music video confirmed the "radically pacifistic" promotional tagline Peszek attributed to this album in the YouTube description. $\underline{105}$

'Modern Holocaust' to drugi singiel promujący album Marii Peszek 'KARABIN', który ukazał się 26 lutego nakładem Warner Music Poland. Do utworu zrealizowany został teledysk, który wyreżyserował Przemek Wojcieszek.

Płytę 'KARABIN' zamówisz na: http://smarturl.it/MariaPeszekKarabin

'KARABIN' to kolejny koncept album artystki, tym razem to jedenaście piosenek o wolności, nienawiści i prawie do bycia innym. Jedenaście piosenek na niespokojne czasy. Radykalnie pacyfistyczne treści przewrotnie zestawione z tytułem. Płyta jest kolejnym projektem współtworzonym przez Marię z Michałem FOXEM Królem

Figure 4. The description of the music video for Peszek's Modern Holocaust

Translation: “'Modern Holocaust' is the second single promoting Maria Peszek's album 'KARABIN' which was released on February 26 by Warner Music Poland. A music video was produced for the piece, directed by Przemek Wojcieszek. You can order the

'KARABIN' CD at: http://smarturl.it/MariaPeszekKarabin. 'KARABIN' is another concept album of the artist, this time it contains

eleven songs about freedom, hatred, and the right to be different. Eleven songs for troubled times. Radically pacifistic content perversely juxtaposed with the title. The album is another project co-created by Maria with Michał FOX Król."

Screenshot taken from Maria Peszek, "Maria Peszek - Modern Holocaust [Official Music Video]," March 8, 2016, accessed November 24, 2020, https://www.youtube.com/watch?v=atJ

\section{“Polska A B C i D” (2016)}

Among all Peszek singles, "Polska A B C i D" has garnered the widest acclaim: number one on the radio charts with over 2.3 million views and a 16k/1.4k like-to-dislike ratio on YouTube. As I will later 
explore, this song was not free from controversies; however, analysing its audiovisual rhetorical strategies and the effectiveness of its remarkable mass appeal yield interesting results. The single's online release was accompanied by a lyric video rather than the theatrical videos of "Ludzie Psy" or "Modern Holocaust." Interestingly, the lyric video did not display the song text precisely as it was sung but replaced multiple words in each verse with sets of emojis, while some parts of the video did not visualise the text at all. The role of emojis quite frequently went beyond merely illustrating what was being said: in a visually simple manner, the seemingly light-hearted images signified emotions (00:51; 01:43), identities and movements (01:12), its ambiguous relation to Poland (02:59), addressed religious groups (1:30; 3:41), created intertextual references (such as AC/DC at 2:40) and added cryptic codes supplementing the lyrics $(0: 44 ; 1: 36)$. Visually cueing a dichotomous split, all visuals within the clip maintained black and white colour schemes, and the screen was divided into two halves through much of the verses and choruses.

\section{Visit the web version of this article to view interactive content.}

Video 3. Maria Peszek, "Maria Peszek - Polska A B C i D [Official Lyric Video],"January 26, 2016, accessed November 24, 2020, https://www.youtube.com/watch?v=5CytySnKHry.

Besides the 'emojified' lyrics synchronised with the audio, the video included seemingly unrelated grainy camera footage from Peszek's personal life: in a car, in a shower, eating, smoking, or gazing at the viewer. In these clips, the artist authenticated herself as we have come to expect: through 'raw' depictions of domestic moments, self-expression, and maintaining contact with her audience.

This element of visual authentication might have been especially significant, considering that this time Peszek's sound was less 'alternative' and lo-fi than usual. Adhering to structural conventions, more melodic and layered (led by vocals and foregrounded piano chords), without unexpected timbres, vocal breaks, or dissonances, the single seemed to be intentionally designed as pop: catchy and radiofriendly.

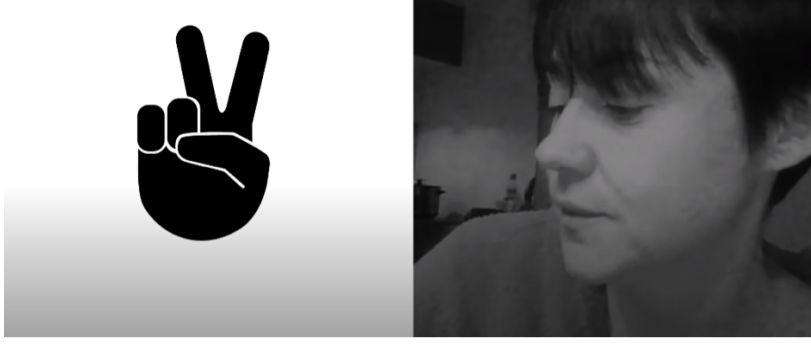

Figure 5. Maria Peszek's personal footage side by side with 'emojified' lyrics. Screenshot taken from Maria Peszek, "Maria Peszek - Polska A B C i D [Official Lyric Video]."

A certain role in this mass appeal quality was played by the titular lyrics reiterated "as sounds"/a "hook" multiple times towards the end of the song, increasing engagement and sing-along potential. $\underline{106}$ The underlying beat mostly remained similarly repetitive, with regular snare reminiscent of clapping - cueing audience participation. This sonic magnetism and visual authentication amplified 
the affective nature of the song's lyrics (see Appendix 4 for full lyrics). The text itself remained undercoded, similar to "Ludzie Psy" in terms of applications to the essentialist parts of Polish identity, mostly forming a general pacifistic, appeasing call against hatred nearly opposite to the radical, straightforward strategies of Pussy Riot. Once more, Peszek highlighted the vulnerability of the marginalised, represented by her character, asking an unidentified addressee - a member of the hegemonic social groups - to "not shoot and let her live." Without specifying which ideologies "Poland A, B, C, i D" represented, what aspects of her character is under threat, or what action should be taken, Peszek keeps the meaning of the song open. Eventually, the exact social critiques derived from "Poland A, B, C, i D" were revealed to be mostly based upon contemporary issues, such as the refugee crisis. .107 The song's bridge, however, presents a more specific critique. Here, a reiterated passage criticised practices of organised religion being used as "envenom" and pointed to such issues in the Polish Catholic Church, just as Pussy Riot called out the political involvements of the Orthodox Church in Russia. This bridge in particular was the source of most controversies related to the song, and wasconsidered by some to be blasphemous or "anti-clerical." $\underline{108}$ Few noticed that in Peszek's lyric video, the emoji of the Catholic cross was included next to the Star of David, Ying-Yang, or the star and crescent, while the artist reiterated the chorus' moralistic line "Because nothing is as it seems/ So don't judge the book by its cover" (03:41). Notably, Peszek chose to sing the latter chorus line in English rather than Polish. For a country to which language is an important part of identity, solidified by the history of struggles for the right to speak it, this is an exceptionally controversial choice, one that could perhaps lead to Peszek to be deemed inauthentic, a Western sellout, "lost in translation," similar to Pussy Riot. $\underline{109}$

Authenticating herself as the performer in the music video, Peszek ensured the song's mass appeal through accessible pop delivery. In fact, some online commenters criticised the opposite of what was pointed out in reviews of her other songs, arguing that now "musically and instrumentally the song is alright, lyrically a few levels below the level Maria made us used to." 110 The sacrifices in radicalism for the sake of undercoded rhetoric and audiovisually mediated mass appeal have been effective in letting "Polska A B C i D" surface in the Polish context and consciousness better than her previous songs did. Despite some controversy, this type of protest - one that steered clear from negating the Polish nationalist identity, while still addressing the hatred present in the contemporary imagined community, and asking for greater inclusion of alternative identities without deeming them inferior certainly appealed to the Polish wider public. Its success could potentially suggest Third Space approaches in-between the Other and the hegemonic, bridging audiovisual stylistics and lyrical rhetorics, might have a special potential for Eastern European protest music. 


\section{“Ej Maria” (2016)}

Due to the comparison drawn in this article, it is crucial to examine Peszek's brand of feminism through a music video wherein she presented her socially perceived gender identity: "Ej Maria." Since the beginning of her career, the criticism towards Peszek was frequently based on her unconventional, androgynous, and 'ugly' look; a gender performance which made many assume she was a lesbian. As Anna Maliszewska, director of the "Ej Maria" music video, explained in the YouTube description, the production team decided to respond to these misrepresentations by amplifying them, thereby making Peszek even more gender non-conforming in the visual narrative of the new single. 111 Peszek's character's masculine performance was shot in Kyiv and set in a 'trashy' hyper-post-Soviet urban environment of grey post-Soviet housing estates (blokowiska). Additionally, it was grounded in the habitus of a working-class Polish "dresiarze" (literally, "tracksuiters") subculture, which positioned it firmly in the local context. $\underline{112}$

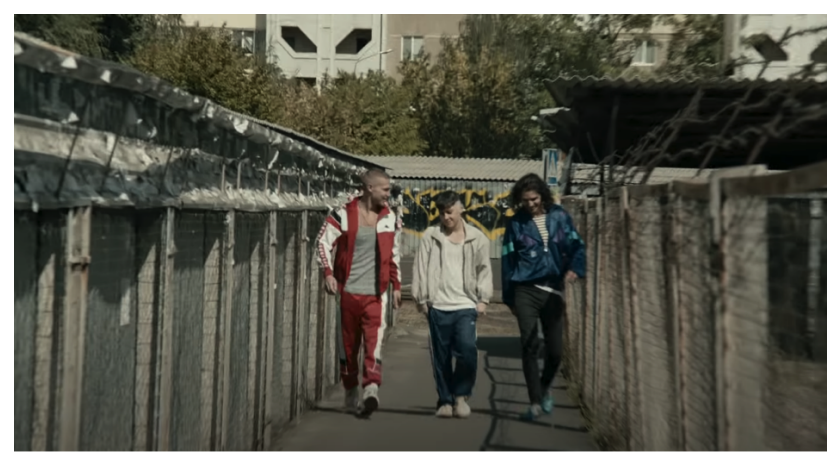

Figure 6. Peszek (middle) accompanied by other "tracksuiters." Screenshot taken from Maria Peszek, "Maria Peszek - Ej Maria [Official Music Video]," September 14, 2016, accessed November 24, 2020, https://www.youtube.com/watch?v=84S6LzU2pRA.
This subculture - considered to be a relic of post-communist "shock therapy" transformations and exclusions - is often assoicated with delinquency, hooliganism, unemploymen, and violence, and is often today conflated with Polish nationalists, due to their frequent adoption of tracksuit clothing. $\frac{113}{\mathrm{In}}$ " $\mathrm{Ej}$ Maria," however, Peszek was presented as accepted within this masculine community, engaging in the same activities. Every bit of her performance was something which, in the

conservative Catholic Polish context, would be seen as deeply inappropriate for a woman and usual for a man: engaging in fights, spitting, screaming, trespassing, lifting weights, and drinking in public. One could recall how Pussy Riot's performance similarly disavowed conventional gender roles with their loud, 'vulgar' performance. However, in Peszek's case, all these actions were set in a realistic postcommunist context rather than in a riot-grrrl-like protest aesthetic; it was only the woman's presence that might have been described as "uncanny" or "defamiliarizing," and required a suspension of disbelief. $\underline{114}$ This authentication of the performer via self-expression was provided in the lyric verses, where Peszek presented a fictional set of advice from an unknown addresser directed at herself (as an artist/musical personae: "Maria"), pointing out how she is unfit for the essentialist, hegemonic majority (see Appendix 5 for full lyrics). Although “Ej Maria's” text was not exactly about feminism or gender, but about Maria Peszek's position as a social outcast, the single was transformative, tying 
these issues into the differences that Peszek "carr[ies] with pride." These words played a rather disjunctive role in relation to the image: the person expressed in the lyrics (a woman who "thinks too much" and "did not cry when the [Polish] pope died") would be unlikely to be accepted into the dresiarze communities. The tolerance of the dresiarze group faded partly in the last scene, wherein Peszek's masculine character kissed one of their male friends: a heterosexual kiss which was nonetheless queered through the protagonist's gender performance, the dominant role they assumed, and through the reaction of the kissed man who instantly pushed Peszek's character away.

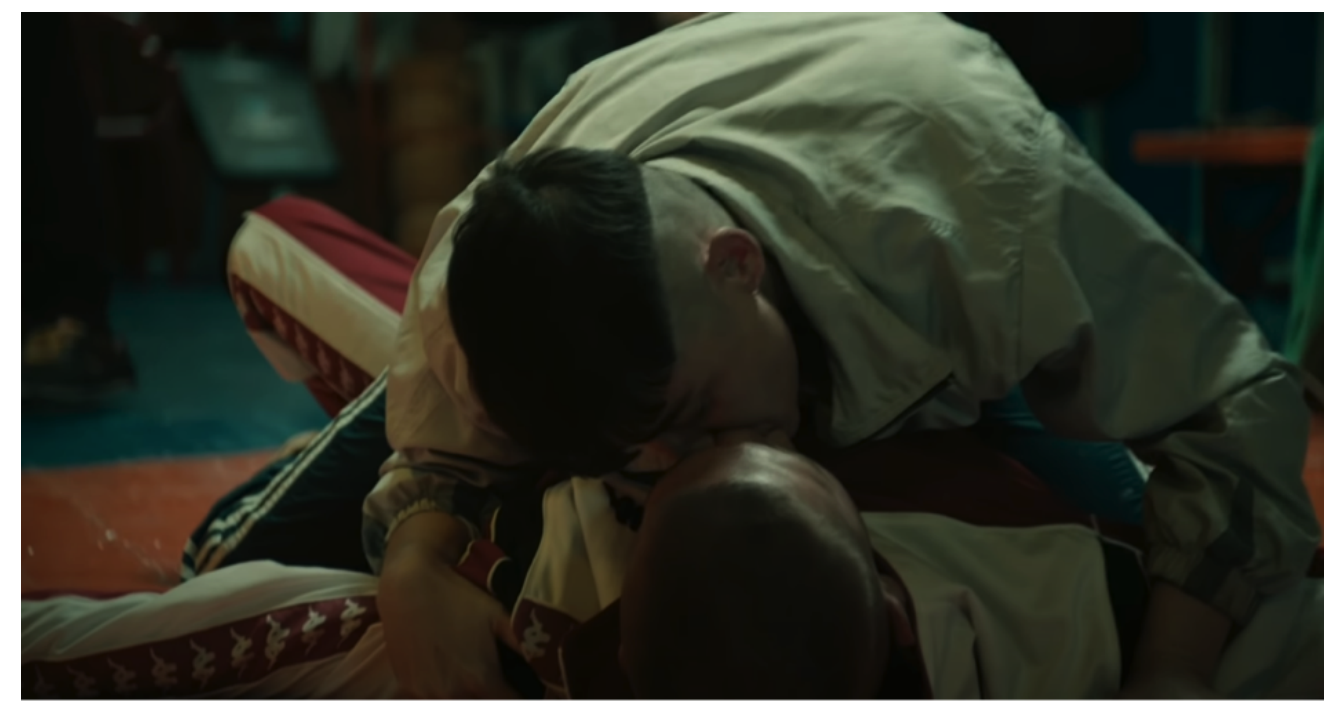

Figure 7. The final kiss. Screenshot taken from Maria Peszek, "Maria Peszek - Ej Maria [Official Music Video].

Despite the general disjuncture between the image and the lyrics, synchronisation points occurred. The most prominent of these occured in the second chorus, where the "If you have it like me / Sing la la la" passage coincided with the video's dresiarze singing along on a crowded bus, establishing, as in "Ludzie Psy," a community of the excluded. For a moment, diegetic sounds briefly replaced Peszek's singing, disrupting the song's flow and introducing some of the visual "beauty in ugliness" (the pillar of the video, as stated in the YouTube description) into the audio. $\underline{115}$

Diegetic sounds were also a part of the audio at the beginning of the video in scenes depicting a morning lifestyle in a post-Soviet working-class household. Apart from these synchronisation points, the music of "Ej Maria" is rather similar to "Polska A B C i D": uplifting, catchy pop with the tune accompanied by piano chords and steady rhythm, as well as Peszek's melodic, only slightly breaking vocals. The reiterated chorus - and especially the diegetic disruption - encouraged participation and engagement, with "la la la" becoming a new authenticating hymn of the Othered.

It is an interesting choice that Peszek decided to frame men from social groups often associated with nationalism as outcasts just like her in "Ej Maria." This might be an additional sign of her attempts at maintaining a unifying, magnetic appeasement/pacifism through appealing to various 
social groups, while speaking not only to those oppressed in terms of belief, gender, or sexuality, but also to the classes at a disadvantage under the post-Soviet, shock-therapy capitalist economy. Such attempts, if effective, legible, and supplemented, could result in her work having significance for more marginalised Poles: benefiting local public debates for inclusion to a greater extent than Pussy Riot, with all its support from abroad, ever did.

\section{Peszek's Music Videos: Assessing Effectiveness}

While the sheer popularity of Peszek's music videos, their chart positions, and platinum awards could already imply her protest song to be effective in garnering mass appeal, it is debatable whether such mainstreaming is enough to make such a claim. To further understand the impact of her music on protest movements in Poland, I will now assess Peszek's relative effectiveness by the three-element definition outlined by Denisoff and Levine that combines various aspects of protest's transformational potential: "significance, legibility, and supplementation." 116 While the first element ("significance" of material to the listener) can be considered partially fulfilled by the commercial success of Peszek's 2012 and 2016 albums, the extent to which her protest messages are "legible" and "supplemented" will now be analysed by employing YouTube-based online anthropology and discourse analysis. The results will then be related to Peszek's chosen audiovisual and rhetorical protest strategies to suggest what aspects of protest song may be effective in the post-communist context in comparison with Pussy Riot.

Jezus Maria Peszek's intentions as stated by the artist (becoming a voice for outcasts) have been identified and explained in many top YouTube comments on the "Ludzie Psy" video. In lengthy clarifications, many Polish viewers shared their interpretations of the song's meaning, while Wojciech Miodoński added that "many people seem to have difficulties with understanding the message of this song." $\stackrel{117}{ }$ Multiple other commenters, such as Alicja Olejnik and Natalia Mirkurda, called out the hatred Peszek has received for her controversy and the hypocrisy of it often coming from Catholics, or praised the artist as exceptional in the music industry.118 Often, the authenticity of Peszek's music video and the approval for her chosen artistic strategies have been highlighted in comments which called "Ludzie Psy" "brave, natural, naturalistic, and surprising," "singing the truth that hurts," "art that provokes, moves," or a "strong, difficult message in good style." 119 Many mentioned the significance of the single as related to their personal stories or confirmed that the music video "hit home." $\stackrel{120}{ }$ Interestingly, this suggests that Peszek's influence was not only limited to a "community of

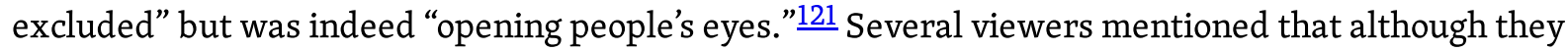
identify with political views opposed to Peszek's, they still consider her "a good artist" who makes 
"music that you can contemplate." $\stackrel{122}{2}$ Later commenters often mentioned the continued relevance of the song in relation to the "worse sort" divisions or the 2020 Polish elections. $\underline{123}$

Among those who were critical of the music video, Peszek received comments mostly attacking her visuals: the unconventional appearance, gender, and the violence depicted in the clip. $\underline{124}$ The raw audio mix and Peszek's vocals were pointed out as lacking were rarer. $\frac{125}{}$ Many of the most critical comments were harsh and vulgar, claiming Peszek to be "insane," "trash," or having lyrics which "make no sense." 126 This backlash, based on either lack of legibility (for some viewers) or dissatisfaction with the radical side of Peszek's audiovisual aesthetics, has been often mimicked in real-life discourse. For example, Peszek's concerts have been opposed by nationalist communities due to supposedly presenting "blasphemous, anti-Polish, and anti-Christian values," and in relation to other controversial songs from the album (“Sorry Polsko"), which Law and Justice’s key politicians, Jarosław Kaczyński and Marek Martynowski, found offense in, stating that "such attitudes should be fought against." $\underline{127}$ Despite the controversies and backlash, "Ludzie Psy" remained significant and legible to most of its YouTube and radio audiences. Its highlighted vulnerability, mass appeal audiovisual/artistic interplay, as well as the single's grounding in the polarised Polish context, all contribute to the acceptance of the song's message, even by some with opposing political views.

Reception to "Modern Holocaust," however, has been more mixed. Albeit grounded in Polish history and contemporary fears, Peszek's supposedly exaggerated, radical historical comparisons generated controversies that initially overrode the positives. For instance, Peszek was criticised for using these harsh parallels only to provoke, doing so without an understanding of the events that she disucssed..$\underline{128}$ At the same time, the parallel choice spoke to many Peszek supporters, who pointed out the metaphorical character of her lyrics in defending her, arguing that the song was authentic, brilliantly depicting Polish reality, and was "only proven" even more by the hateful comments. $\frac{129}{}$ This two-fold reaction, also seen from the song's less conclusive like-to-dislike ratio (16k/8.6k), was a result of Peszek's strategic choice to ground the song in the Polish context through well-recognised, yet painful references. "Modern Holocaust's" re-articulation challenged the idea of Polish essentialist identity as sacred, always on the victim's side of history, resulting in harsh reactions from those strongly dependent on nationalistic identification. The audiovisual interplay of the music video was, unfortunately, barely discussed or outright said to be weaker. $\underline{130}$ The apocalyptic minimalism of Peszek's video and sound did not amplify the single's message enough which might be one additional reason for the song's lesser mass appeal. Hence, "Modern Holocaust" lacked a magnetic quality to go alongside its rhetoric, which could make both liberal and conservative audiences question the lyrics more, without an emotional affect inspiring them to embrace the message. 
Finally, the rhetorically pacifistic choice to apply the anti-hate message to everyone in the chorus received mixed reactions: from liberals calling Peszek to take a consistent stance, to those who appreciated the acknowledgement of two-way hatred, even if their views remained right-wing. $\frac{131}{13}$ Interestingly, "Modern Holocaust's" more recent comments have seen far less questioning of whether Peszek's comparisons were not too much, and more acknowledgment of the actuality and universality of the single in regards to recent events. The reelection of Law and Justice president Andrzej Duda, infamous for anti-LGBTQ + rhetoric, and the conservative attacks at Białystok Pride participants, were mentioned by many as adhering to Peszek's "Modern Holocaust." $\underline{132}$ Referring to personal experiences, recent viewers pointed out their newfound understanding based on this contemporary context. $\frac{133}{}$ As such, the initially lesser legibility of "Modern Holocaust's" message seems to be increasing over time, along with the new significance generated by changing circumstances. Even if there was little focus on the song's audiovisual aspects, I suggest that the undercoding and apocalyptic imagery and sound of the music video played an important role in this development, making "Modern Holocaust" relevant for multiple contexts.

With its radical-pacifistic, anti-hate message and accessible aesthetics, "Polska A B C i D" has become Peszek's most widely acclaimed song by far. Although the bridge lyrics have been at times criticised for "anti-clericalism," divisive and religious hatred, it was more accepted than her previous output. $\underline{134}$ This could either be due to the minimal inclusion of radical ideas in the generally pacifistic song lyrics, or the possibility to relate the lyrics only to certain negative individuals in the Polish Catholic Church rather than to the Catholic faith in general. $\frac{135}{2}$ Most comments posted on YouTube to the music video highlighted the truthfulness, authenticity, and relevance of its rhetorical messages in relation to the contemporary context that included the 2020 elections and the Bialystok Pride attacks, at times even stating that Peszek "predicted the future." $\underline{136}$

Wider discussions about the divisions of Poland communicated in "A B C i D" have been applied by commenters to a variety of possible axes of exclusion, depending on their personal experiences or views. Apart from focusing on dividing of Poles into 'better' and 'worse,' or LGBTQ+ discrimination, commenters additionally focused on the treatment of Polish subcultures, such as rural populations, "rainbows" (the LGBTQ+ community), and those who would not accept "right-wing views." 137 Due to lyrical undercoding and vagueness, some viewers found the text to be "a few levels below the standard that Maria got us used to," however the single was praised as "ambitious" even by those affirming themselves as disagreeing with Peszek's rhetoric. $\frac{138}{}$ Several viewers pointed to the significance of its mass appeal magnetism as supporting the pacifistic rhetorical messages and to the engagement and singing participation encouraged by the song. $\frac{139}{}$ Lyric video choices were hardly opined upon, with comments regarding radio or live dissemination of the single taking the forefront. This might suggest 
that visual YouTube uploads were not the primary mode of experiencing the single, which is why some of the coded visual messages might have been missed.

Those criticising the song usually relied on mentioning Peszek's background, referring to her previous leftist-coded career to challenge the authenticity of her call for acceptance. $\underline{140}$ Additionally, some criticised her choice to use an English line in the chorus, describing it as unnecessary, badly pronounced, or kitschy. $\underline{141}$ Despite these critiques, the song has been largely embraced in terms of both YouTube views and chart success, and has generated a broad scope of interpretative applications from various sides of the Polish political spectrum. likely due to the combination of undercoded pacifistic lyrics and mass appeal audio. Its significance could then be said to be outstanding in terms of scope. This broad scope has also caused the legibility of the protest message to be related to a multiplicity of contemporary events by a variety of social groups, with its authenticity and universality only questioned in regards to Peszek's past or the bridge rather than the song's audiovisual and textual core.

"Ej Maria's" self-expressive music video has led to fewer debates on the lyrics or the condition of the Polish society. Instead, many YouTube commenters focused on the visual side of the clip and the participatory nature of the song's chorus. Peszek's non-conforming gender performance has been opined upon most often: either as an "amazing creation" which affirmed her acting skill; as breaking the music industry conventions for women's music videos and stereotypes of women in general; as a source of provocation; or as "disgusting." 142 Meanwhile, the single's sonic side has been related to mainly through the reiteration of the sing-a-long chorus line, which appears to have become the new hymn of the outcasts, with many viewers simply writing "LA LA LA!" as if singing along with the artist. $\underline{143}$ The participatory nature of “Ej Maria” has also been highlighted by some commenters directly responding to the ultimatum Peszek presented in the song's lyrics - "freedom or fear." 144 Overall, the song could have had a lesser impact and potentially more self-expression and rearticulation, which is perhaps why fewer found it to be legible as firmly political. However, its significance and legibility could still be sought in the identification many assumed with Peszek's self-expression by means of participatory involvement (with both the audio and lyrics) in the comments.

Beyond YouTube and towards embodied protest, the analysed singles and music videos released by Peszek have led to several noteworthy participatory and real-life supplementations of their messages and influence. As already mentioned, "Polska A B C i D's" lyrics were adopted for use on Manifa posters (see Figure 6) while various Peszek's protests songs have been also reported to have been played at feminist, anti-war, anti-fascist, and anti-hate demonstrations throughout the country. $\underline{\underline{145}}$ Most recently, the All-Poland Women's Strike has likewise brought Peszek's song back into the public eye, as 
her lyrics continued to appear on banners, while her songs were played, sung and added to user-made Spotify protest playlists associated with the strike. $\underline{146}$

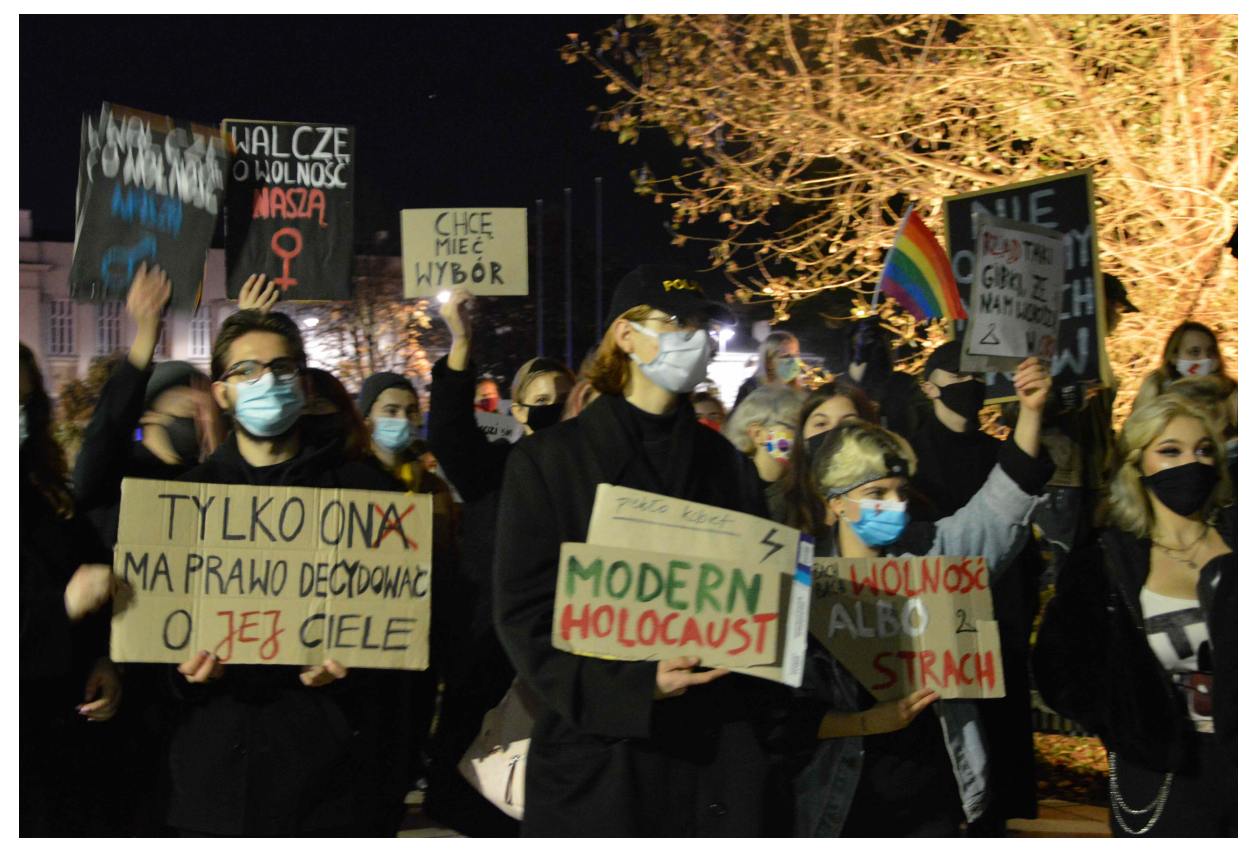

\footnotetext{
Figure 8. Peszek's song lyrics used on protest banners. Taken from DSM, “'Strajk Kobiet', '********' i 'Moje ciało, moj wybór'. Przez Lublin przeszedł kolejny protest przeciwników decyzji Trybunału https://www.lublin24, pl/wiadomosci/straik-kobiet-i-moje-cialo-moj-vyber 24, 2020, kolejny-protest-przeciwnikow-decyzji-trybunalu-galeria/Xh805d93koijt610hgg
}

On Facebook and Twitter, \#modernholocaust has been often used to refer to Polish political events. By Peszek's initiative, the chorus from "Ej Maria" also gained new meanings for the 2020 presidential elections, with posters in the shape of the Polish emblem and the colours of the Polish flag bearing the slogan "Either freedom or sand" being distributed by those opposing the Law and Justice party. $\frac{147}{}$ As such, one can notice the significance of Peszek's songs and their relative (but impressive for popular music standards) legibility. In continuously being addressed in the public debate and driving contemporary protests, the politics of her music are also, to an extent, supplemented. 
Peszek has used various strategies of protest throughout her musical career, from Pussy-Riotlike disruptive and radical performativity, to pacifistic and peace-making portrayals.

However, it was ultimately steering clear from negating dominant Polish identities (while still supporting transformations and rearticulations), and an authenticity-affirming, mass appeal audiovisual packaging, that allowed her the widest acclaim in "Polska A B C i D." Her music overall has achieved an impressive significance and legibility that encompassed even some opposing and moderate political views, as well as supplementation in real-life protests and on other platforms. As I suggest, if one aims for effectiveness, performing nationality and grounding the protest in context in order to acquire a position within the imagined community (despite differences between these two dichotomies) is crucial. This importance lies in the attribution of authenticity by local audiences, who perceive Peszek's expressions in music as products of an authentic artistprotester, a relatable Polish woman, and an understood role model, rather than just a strategically used musical persona or a 'foreign threat' similar to Pussy Riot. Ultimately, it was the undercoded, radically pacifistic, and magnetic form of "Polska A B C i D" that acquired the widest mass appeal, engagement, and became frequently cited in Polish public discourse. The effectiveness of Peszek's protest songs were achieved through careful negotiations between the radical and popular within a Third Space. Specifically, this has seen Peszek self-Othering while still promoting the peacemaking 'we're all the same' rhetoric; calling for both action and pacifistic alleviation; combining shock tactics in her performances with a catchy pop sound; all combined in an audiovisual interplay that balanced the words by making them more disruptive or accessible depending on the need. This paradoxical, but well-functioning blend allowed her music to become immensely popular within Poland - an effect which Pussy Riot's protest style could not achieve within its own domestic sphere. As such, if "Punk Prayer" is seen as failing to inspire discussion and arouse protest sentiments within its local context, Maria Peszek was successful with her balanced multimedia music tailor-made for the nation it emerged from. 


\section{Conclusion}

The local, national identities and its context have an immense influence on the ways protest needs to be framed if it is to be perceived as authentic and magnetic. As my analysis of Pussy Riot has shown, the Western aesthetics of radical protest when applied in Eastern Europe may result in a portrayal of protest as Western-orchestrated or anti-national, effectively allowing for its exploitation. According to Yablokov, framing Pussy Riot as a part of a Westerniser conspiracy allowed the Kremlin to advance their "neo-traditional values agenda." 148 This outcome was avoided by Peszek. Although she has received a considerable amount of criticism, the claims of her being anti-Polish did not catch on in the majority of Polish society. As such, despite her anti-essentialist attempts to re-articulate Polishness, she has claimed authenticity not only as a musical persona but as a genuine artist-protester within the imagined community. Effectively, she achieved chart and award success, as well as the support of many Poles in the online discourse, which led her to become one of the most recognised protest artists in contemporary Poland.

The most popular of her songs have fulfilled four requirements: steering clear from negating dominant identities, instead subverting them in a Third Space, elective; performing the knowledge of Polish context, sentiments, and histories; combining radical and pacifistic strategies; and being delivered in a well-balanced blend of disruptive and mass appeal audiovisual stylistics. Although artistic protest may aim for radicalism, and such types of protest are often recognised in the Western World, many Eastern European activists do not see forms of protest such as Pussy Riot's "Punk Prayer" as "advancing the feminist cause," but rather wishing to promote change through less radical means which appeal to wider social groups. Peszek has certainly resonated with Polish society better than Pussy Riot did with Russian women. $\underline{149}$ This can be seen as a result not only of Polish society being closer to the West, but also of her protest functions combining the rhetorical and magnetic, protest strategies mixing the disruptive and accessible, and the way in which she managed to bring the radical into the domain of the popular, making it significant, legible, and supplemented. As such, I argue that Peszek's forms of protest grounded in the Eastern European context are more effective, at least in the short run, than Pussy Riot's Westernised, riot-grrrl style.

This argument may be expanded to conclude that there are no universal ways to protest. Following the American model of radical, disruptive intersectionality as a path to transformations and rearticulations of national and gender identities may not be the best choice for another national context. Instead, the artist-activists of each cultural context need to develop contextually relevant protest expressions, aesthetics and forms, gradually creating their own "consciousness-raising processes" which can be incorporated into an articulation of new, intersectional national identities over time. $\underline{150}$ 
For strongly essentialist nations which remain in transition after the recent communist/Soviet regime histories, this may be particularly crucial: as a way to ensure that social justice and progressive change messages in protest are understood as native and authentic - not simply dismissed as an influence of foreign agenda. $\underline{151}$

\title{
Appendices
}

\section{Appendix 1.}

\author{
“Punk Prayer" translated lyrics: \\ Virgin Mary, Mother of God, banish Putin \\ Banish Putin, Banish Putin!
}

Congregations genuflect

Black robes brag, golden epaulettes

Freedom's phantom's gone to heaven

Gay Pride's chained and in detention

The head of the KGB, their chief saint

Leads protesters to prison under escort

Don't upset His Saintship, ladies

Stick to making love and babies

Crap, crap, this godliness crap! 
Crap, crap, this holiness crap!

Virgin Mary, Mother of God

Become a feminist, we pray thee

Become a feminist, we pray thee

Bless our festering bastard-boss

Let black cars parade the Cross

The Missionary's in class for cash

Meet him there, and pay his stash

Patriarch Gundyaev believes in Putin

Better believe in God, you vermin!

Fight for rights, forget the rite -

Join our protest, Holy Virgin

Virgin Mary, Mother of God, banish Putin, banish Putin

Virgin Mary, Mother of God, we pray thee, banish him!

\section{Appendix 2.}

\section{“Ludzie Psy” [“Dog People”] translated lyrics:}

My whole world went bankrupt today 
Now I know how it is to lose on the stock market of despair.

I've got fire in my head and grey smoke in my heart.

God abandoned me, I got completely blotto.

I'm the bad side of nation, I'm a splinter under the skin,

Meat of the soul, I'm porn, I'm mush.

I'm a black cat, a furious dog,

I'm a weed and a scar.

I'm the only motherland of unwanted words.

For you scratching scabs of ideas,

For you binding words into kinks,

For you the queen of trash is singing songs of mold

Mutts, weirdos, punks, loonies

Degenerate citizens

Ey, arsonists of souls, let's make smoke

Hey, you! Dog people

Your fur is wet.

Hey, we'll eat grief with spoons today.

\section{Appendix 3.}




\section{“Modern Holocaust" translated lyrics:}

In my country they're burning a rainbow

Just like once they've burned people in the stable

Our Polish hate and butter

As common as bread, as a dinner on the table

What Hitler or Stalin didn't destroy

What ZOMO didn't kill

What Auschwitz oven didn't manage to burn

Polish furious dog of hate will devour

Letter, letter, letter in a white envelope

Someone, someone threatens to kill me

You stink like a dyke, you leftist scum

Stupid bitch, Jewish whore

Today, today they've written online to me

I will destroy you, fucking kill you and drain you in the toilet

You stink like a dyke, you leftist scum

You are mental, bitch, I'll get you for sure

'Cause it's not that the evil is Hitler or Stalin

Evil is inside all of us

Evil is made by us 
'Cause it's not that the evil

Is Putin or Bin Laden

You also have in your house

Your own rifle

In my country of hatred

Everyone hates everyone

What Hitler, Stalin didn't fuck up

We are destroying and fucking up on our own

An enormous fire of Polish hatred is burning

Nowhere to escape, nowhere to run

And just like a draught of dirty vodka, Polish Modern Holocaust

\section{Appendix 4.}

‘Polska A B C i D” [“Poland A B C and D"] translated lyrics:

I want to eat, I want to drink

I want to love, I want to dream

I want to scream, I want to run

I want to want

Everything divides us, nothing unites

Let me be myself, let me live

Different doesn't mean worse or bad 
Don't shoot please, let me be

Because nothing is as it seems

So don't judge a book by its cover

Don't be afraid to be afraid, don't be afraid to stay in place

Don't be afraid to do nothing, don't be afraid to sleep without dreams

But when the day comes - and this time is now

Open your eyes and jump

One can envenom by word, one can envenom by prayer

One can divide people, cut with a cross like a razor

One can envenom by word, one can envenom by prayer

One can divide Poland, cutting with a cross like with a razor

Poland A, Poland B, Poland A, B, C and D

\section{Appendix 5.}

'Ej Maria" translated lyrics:

Ey Maria

Don't think so much

Your legs are straight

And your thoughts knock-kneed 
And you sing things

Like from space

And you did not cry

When the pope died

You carry your difference

Like Jedi his light saber

And like a fucking saint

You prefer to be rather than have

If you have it like me

Shout la la la

If you feel like me

Shout la la la

Bach bach

Either freedom or fear/sand

Bach bach

Freedom or fear/sand

Hey Maria

Don't think that much

Your legs are straight

And your thoughts knock-kneed 
You walk where there's no entry

And you have a strange weakness

For dangerous thoughts

And unguarded beaches

And that bomb inside your head

You carry with pride like medals

Which you shall never get

Yet which you also don't want at all

\section{Biblography}

Anderson, Benedict. Imagined Communities: Reflections on the Origin and Spread of Nationalism. London: Verso, 2006.

Archiwum Listy Przebojów Trójki. “Notowanie 1609.” LP3, November 30, 2012. Accessed November 23, 2020. https://www.lp3.pl/notowanie/1609.

Archiwum Listy Przebojów Trójki. “Notowanie 1781.” LP3, March 18, 2016. Accessed November 23, 2020. https://www.lp3.pl/notowanie/1781.

Ashwell, Lauren. “Gendered Slurs.” Social Theory and Practice 42, no. 2 (2016): 228-39.

Ashwin, Sarah. "Introduction: Gender State and Society in Soviet and Post-Soviet Russia." In Gender, State and Society in Soviet and Post-Soviet Russia, edited by Sarah Ashwin, 1-29. London and New York: Psychology Press, 2000.

Auslander, Philip. “On the Concept of Persona in Performance." Kunstlich 31, no. 3 (2015): 62-79.

Auslander, Philip. “Framing Personae in Music Videos." In The Bloomsbury Handbook of Popular Music Video Analysis, edited by Lori A. Burns and Stan Hawkins, 91-109. New York and London: Bloomsbury 
Academic, 2019.

Beathy, Thalia. "Strike to Win: Can Polish Feminists Turn Protest Into Power?” Dissent Magazine, Summer 2017. https://www.dissentmagazine.org/article/poland-feminists-strike-manifa-razemprotest-power.

Bhabha, Homi K. Nation and Narration. London and New York: Routledge, 1990.

Bhabha, Homi K. The Location of Culture. 2nd edition. London and New York: Routledge, 2004.

Bińczycki, Jan. “Siekiera, Motyka, Czarny Protest.” Onet Kultura, November 30, 2016. Accessed November 23, 2020. https://kultura.onet.pl/wiadomosci/siekiera-motyka-czarny_protest/2yqyn64.

Bollin, Przemysław. “Maria Peszek: Holocaust Nigdy się nie Skończył [Wywiad].” Onet Muzyka, February 26, 2016. Accessed November 23, 2020. https://kultura.onet.pl/muzyka/wywiady-iartykuly/maria-peszek-holocaust-nigdy-sie-nie-skonczyl-wywiad/bnh443w.

Broda, Tomasz, “Pejzaż z Narodowcem, czyli Horror i Ojczyzna,” Tygodnik Wrocław Wyborcza, November 13, 2015. Accessed November 24, 2020. https://wroclaw.wyborcza.pl/wroclaw/1,142076,19181701,pejzaz-z-narodowcem-czyli-horror-iojczyzna-rysunki-brody.html.

Brzezinski, Zbigniew. The Soviet Bloc, Unity and Conflict. Cambridge: Harvard University Press, 1967.

Bunikowski, Dawid. “The Constitutional Crisis in Poland, Schmittian Questions, and Kaczyński's Political and Legal Philosophy." Journal of Contemporary European Studies 26, no. 3 (2018): 285-307.

Burns, Lori. “Dynamic Multimodality in Extreme Metal Performance Video: Dark Tranquility's 'Uniformity,' Directed by Patric Ullaeus." In The Bloomsbury Handbook of Popular Music Video Analysis, edited by Lori A. Burns and Stan Hawkins, 91-109. New York and London: Bloomsbury Academic, 2019.

Butler, Judith. "Performative Acts and Gender Constitution: An Essay in Phenomenology and Feminist Theory." Theatre Journal 40, no. 4 (1988): 519-31.

Chion, Michel. Audio-Vision: Sound on Screen. New York: Columbia University Press, 1994.

Chmielewska-Szlajfer, Helena. Reshaping Poland's Community after Communism: Ordinary Celebrations. Warsaw: Palgrave Macmillan, 2019.

Cieśla, Wojciech. “PiS: First we Take Podlasie." Newsweek Polska, July 24, 2013. Accessed November 24, 2020. https://www.newsweek.pl/polska/pis-first-we-take-podlasie-newsweekpl/vnrgltz. 
Cross, Anthony. “'Them': Russians on Foreigners." In National Identity in Russian Culture: An Introduction, edited by Simon Franklin and Emma Widdis, 74-92. Cambridge: Cambridge University Press, 2004.

Culture.pl. “Maria Peszek.” Culture.pl, November 1, 2014. Accessed November 23, 2020. https://culture.pl/en/artist/maria-peszek.

Damodaran, Sumangala. "Protest and Music." Oxford Research Encyclopedia of Politics, August 5, 2016. Accessed November 23, 2020.

https://oxfordre.com/politics/view/10.1093/acrefore/9780190228637.001.0001/acrefore$\underline{9780190228637-e-81 \text { ?result }=2 \& \text { rskey }=205 \text { QAq. }}$.

Demaria, Cristina. "The Performative Body of Marina Abramović: Rerelating (in) Time and Space." European Journal of Women's Studies 11, no. 3 (2004): 295-307.

Denisoff, Serge R. Sing a Song of Social Significance. Bowling Green: Bowling Green State University Popular Press, 1983.

Denisoff, Serge R., and Mark H. Levine. “The Popular Protest Song: The Case of 'Eve of Destruction'." Public Opinion Quarterly 35, no. 1 (1971): 117-122.

DSM. “'Strajk Kobiet', "********’ i 'Moje ciało, mój wybór’. Przez Lublin przeszedł kolejny protest przeciwników decyzji Trybunału [GALERIA].” Lublin24.pl, October 24, 2020. Accessed November 24, 2020. https://www.lublin24.pl/wiadomosci/strajk-kobiet-i-moje-cialo-moj-wybor-przez-lublinprzeszedl-kolejny=protest-przeciwnikow-decyzji-trybunalu-galeria/Xh805d93koiJt61UhggE.

Duncan, Peter J. S. “Contemporary Russian Identity between East and West.” The Historical Journal 48, no. 1 (2005): 277-94.

Dybiec, Aleksandra. “'Bluźnierczy i Antypolski’. Senator PiS o Koncercie Marii Peszek." Wyborcza Płock, September 4, 2013. Accessed November 24, 2020. http://plock.wyborcza.pl/plock/1, 35681, 14549818,_Bluznierczy_i antypolski Senator PiS o koncer cie.html.

Geslani, Michelle. "Watch: Pussy Riot's historic 'A Punk Prayer' performance on its 2-year anniversary." Consequence of Sound, February 21, 2014. https://consequenceofsound.net/2014/02/watch-pussy-riotshistoric-a-punk-prayer-performance-on-2-year-anniversary $/$.

Eyerman, Ron, and Andrew Jamison. Music and Social Movements: Mobilizing Traditions in the Twentieth Century. Cambridge: Cambridge University Press, 1998. 
Gal, Susan, and Gail Kligman. Reproducing Gender: Politics, Publics, and Everyday Life after Socialism. Princeton: Princeton University Press, 2000.

Gan, Gregory. "Soaring to Dizzying Heights: Christ the Saviour Cathedral as a Historical Arena for the Persecution of Pussy Riot." Critique of Anthropology 35, no. 2 (2015): 166-86.

Garczewski, Krzysztof, and Anna Garczewska. "Sounds of the Opposition - Music and Politics in Poland 1970-1989." Confrontation and Cooperation: 1000 Years of Polish-German-Russian Relations: The Journal of Kolegium Jagiellonskie Torunska Szkola Wyzsza 1, no. 1 (2014): 45-55.

Goodwin, Andrew. Dancing in the Distraction Factory: Music Television and Popular Culture. Minneapolis: University of Minnesota Press, 1992.

Gulda, Przemysław. “Maria Peszek- Stare Piosenki, Ważne Gesty.” Wyborcza, January 31, 2020. Accessed November 23, 2020. https://trojmiasto.wyborcza.pl/trojmiasto/7,35611,25648177, mariapeszek-stare-piosenki-wazne-gesty.html.

I-D Staff. “ITunes Ocenzurował Marię Peszek.” I-D Vice, February 23, 2016. Accessed November 23, 2020. https://i-d.vice.com/pl/article/bjmd53/itunes-ocenzurowal-marie-peszek.

Issoupova, Olga. "From Duty to Pleasure?: Motherhood in Soviet and Post-Soviet Russia." In Gender, State and Society in Soviet and Post-Soviet Russia, edited by Sarah Ashwin, 30-54. London and New York: Psychology Press, 2000.

Jahn, Hubertus F. “'Us’: Russians on Russianness.” In National Identity in Russian Culture: An Introduction, edited by Simon Franklin and Emma Widdis, 53-72 .Cambridge: Cambridge University Press, 2004.

Jarocki, Jacek. “Maria Peszek- Karabin.” Muzyczny Horyzont, September 2, 2017. Accessed November 23, 2020. http://www.muzycznyhoryzont.pl/maria-peszek-karabin/.

Jenzen, Olu. “The Queer Uncanny.” eSharp 9, no. 1 (2007).

Johnson, Janet E., and Aino Saarinen. "Twenty-First-Century Feminisms under Repression: Gender Regime Change and the Women's Crisis Center Movement in Russia." Signs 38, no. 3 (2013): 543-67.

Jś. “Maria Peszek Wróciła i Nadal nie Lubi Kościoła. Posłuchaj Piosenki Polska A B C i

D." Wyborcza, January 26, 2016. Accessed November 23, 2020.

https://wyborcza.pl/1,75410,19539375, maria-peszek-wrocila-i-nadal-nie-lubi-kosciola-posluchajpiosenki.html. 
Kiblitskaya, Marina. “Russia's Female Breadwinners: The Changing Subjective Experience.” In Gender, State and Society in Soviet and Post-Soviet Russia, edited by Sarah Ashwin, 55-70. London and New York: Psychology Press, 2000.

Kutschke, Beate. "Political Music and Protest Song." In Protest Cultures: A Companion, edited by Kathrin Fahlenbrach, Martin Klimke, and Joachim Scharloth, 264-71. New York and Oxford: Berghahn, 2016.

Mackrael, Kim, and Bill Curry. "Pussy Riot Draws International Support after Guilty Verdict." The Globe and Mail, August 17, 2012. Accessed November 23, 2020.

https://www.theglobeandmail.com/news/world/pussy-riot-draws-international-support-after-guilty= verdict/article4487711/.

Marzec, Andrzej. “'Nie Pytaj mnie, co Widzę w Niej' ('Do not Ask me what I See in Her') - Abandoning Poland in Contemporary Music." Czas Kultury 34, no. 3 (2018): 55-61.

Middleton, Richard. Studying Popular Music. Milton Kenyes and Philadelphia: Open University Press, 1990.

Moore, Allan. "Authenticity as Authentication." Popular Music 21, no. 2 (2002): 209-23.

Mortensen, Antonia, and Laura Smith-Spark. "Poland's Biggest Protests in Decades Stand against Abortion Ban." CNN, October 31, 2020. Accessed November 24, 2020.

https://edition.cnn.com/2020/10/31/europe/poland-abortion-protests-scli-intl/index.html.

Nowak, Marta K. “Bunt Kobiet Silniejszy niż Izolacja. Rusza Ogólnopolski Protest przeciwko Zakazowi Aborcji." OKO.Press, April 11, 2020. Accessed November 23, 2020. https://oko.press/bunt-kobietsilniejszy-niz-izolacja-rusza-ogolnopolski-protest-przeciwko-zakazowi-aborcji/.

OLiS. “Oficjalna Lista Sprzedaży: Sales for the Period 01.10.2012-07.10.2012.” OLiS, October 7, 2012. Accessed November 23, 2020. http://olis.onyx.pl/listy/index.asp?idlisty=770\&lang=en.

OLiS. “Oficjalna Lista Sprzedaży: Sales for the Period 26.02.2016-03.03.2016." OLiS, March 3, 2016. Accessed November 23, 2020. http://olis.onyx.pl/listy/index.asp?idlisty=1010\&lang=en.

P.Mal. “Andrzej Duda o LGBT: Próbują Wmówić, że to Ludzie. To Ideologia.” Rzeczpospolita, June 13, 2020. Accessed November 23, 2020. https://www.rp.pl/Wybory-prezydenckie-2020/200619782Andrzej-Duda-o-LGBT-Probuja-wmowic-ze-to-ludzie-To-ideologia.html.

Pasternak-Mazur, Renata. “The Black Muse: Polish Hip-Hop as the Voice of 'New Others' in the PostSocialist Transition." Music E Politics 3, no. 1 (2009). 
Peszek, Maria. “DZISIAJ! \#wyboryprezydenckie2020 \#future \#przyszłość \#polska.” Facebook, June 28, 2020. Accessed November 24, 2020.

https://www.facebook.com/peszekmaria/photos/a.455421470201/10158203076930202/.

Polish Feminists. “Nasz Ulubiony Plakat z Warszawskiej \#Manifa.” Twitter post, March 5, 2019.

Accessed November 23, 2020. https://twitter.com/i/web/status/1102905181921034240.

Powys Maurice, Emma. “A Third of Poland has now been Declared an 'LGBT-Free Zone', Making

Intolerance Official." Pink News, February 25, 2020. Accessed November 23, 2020.

https://www.pinknews.co.uk/2020/02/25/third-of-poland-lgbt-free-zone-atlas-of-hate-homophobia/?

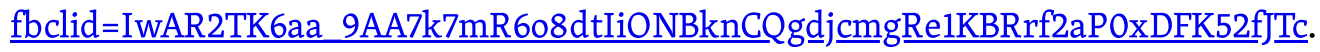

Prozorov, Sergei. "Pussy Riot and the Politics of Profanation: Parody, Performativity, Veridiction." Political Studies 62, no. 4 (2013): 766-83.

Przylipiak, Wojciech. "Maria Peszek: Chciałam Skupić się na Nienawiści, ale Wyszła Płyta o Wolności [WYWIAD]." Dziennik.pl, February 26, 2016. Accessed November 23, 2020.

https://muzyka.dziennik.pl/news/artykuly/514147,maria-peszek-wywiad-nowa-plyta-karabin-polskaa-b-c-i-d.html.

Puścikowska, Agata. “Byłam na Manifie.” Gość.pl Warszawski, March 10, 2013. Accessed November 24, 2020. https://warszawa.gosc.pl/doc/1481241.Bylam-na-Manifie/4.

Riabova, Tatiana, and Oleg Riabov. "The Real Man of Politics in Russia (On Gender Discourse as a Resource for the Authority)." Social Sciences 42, no. 3 (2011): 58-71.

Riabov, Oleg, and Tatiana Riabova. "The Remasculinization of Russia?: Gender, Nationalism, and the Legitimation of Power Under Vladimir Putin." Problems of Post-Communism 61, no. 2 (2014): 23-25.

Rutland, Peter. “The Pussy Riot Affair: Gender and National Identity in Putin's Russia." Nationalities Papers: The Journal of Nationalism and Ethnicity 42, no. 4 (2014): 575-82.

Scally, Derek. "Polish National Broadcaster Turns into Propaganda Machine." The Irish Times, May 19, 2016. Accessed November 23, 2020. https://www.irishtimes.com/news/world/europe/polish-nationalbroadcaster-turns-into-propaganda-machine-1.2652527.

Sie Kręci. "Maria Peszek Wystąpi po raz Pierwszy na Dużej Scenie Przystanku Woodstock." PolskieRadio24 Trójka, March 28, 2013. Accessed November 23, 2020. https://www.polskieradio24.pl/9/1697/Artykul/811916,Maria-Peszek-wystapi-po-raz-pierwszy-naduzej-scenie-Przystanku-Woodstock. 
Slack, Jennifer Daryl. “The Theory and Method of Articulation in Cultural Studies.” In Stuart Hall: Critical Dialogues in Cultural Studies, edited by David Morley and Kuan-Hsing Chen, 113-129. London: Routledge, 1996.

Snitow, Ann, and Katheryn Detwiler. “Gender Trouble in Poland.” Dissent Magazine, Fall 2016. https://www.dissentmagazine.org/article/gender-trouble-poland-pis-abortion-ban.

Strzelecka, Marta. “Maria Peszek: Można z tego Piekła Wrócić.” Wprost, September 30, 2012. Accessed November 23, 2020. https://www.wprost.pl/tylko-u-nas/350196/maria-peszek-mozna-z-tego-pieklawrocic.html.

Strzelecka, Marta. “Maria Peszek - Pełny Wywiad. 'Trudno jest być innym'.” Wprost, October 4, 2012. Accessed November 23, 2020. https://www.wprost.pl/tylko-u-nas/350964/Maria-Peszek-pelny= wywiad-Trudno-jest-byc-innym.html.

Sonevytsky, Maria. "The Freak Cabaret on the Revolution Stage: On the Ambivalent Politics of Femininity, Rurality, and Nationalism in Ukrainian Popular Music." Journal of Popular Music Studies 28, no. 3 (2016): 291-314.

Tochka, Nicholas. "Cosmopolitan Inscriptions?: Mimicry, Rap, and Rurbanity in Post-Socialist Albania." In Hip Hop at Europe's Edge: Music, Agency, and Social Change, edited by Milosz Miszczynski and Adriana Helbig, 165-81. Bloomington and Indianapolis: Indiana University Press, 2017.

Vanderhaeghen, Yves Nicholas. "Other than Ourselves: an Exploration of 'Self-Othering' in Afrikaner Identity Construction in Beeld Newspaper." PhD diss., University of KwaZulu-Natal, 2014.

Vernallis, Carol. “The Functions of Lyrics in Music Video." Journal of Popular Music Studies 14, no. 1 (2002): 11-31.

Vernallis, Carol. Unruly Media: YouTube, Music Video, and the New Digital Cinema. Oxford and New York: Oxford University Press, 2013.

Walsh, Colleen. "Stonewall Then and Now." The Harvard Gazette, June 27, 2019. Accessed November 24, 2020. https://news.harvard.edu/gazette/story/2019/06/harvard-scholars-reflect-on-the-history-andlegacy-of-the-stonewall-riots/.

Wąs, Stasia. "Maria Peszek jest Dresiarzem!" I-D Vice, September 15, 2016. Accessed November 24, 2020. https://i-d.vice.com/pl/article/zm4wya/maria-peszek-jest-dresiarzem.

Weisethaunet, Hans, and Ulf Lindberg. "Authenticity Revisited: The Rock Critic and the Changing Real." Popular Music and Society 33, no. 4 (2010): 465-85. 
Yusupova, Marina. "Pussy Riot: a Feminist Band Lost in History and Translation." Nationalities Papers: The Journal of Nationalism and Ethnicity42, no. 4 (2014): 604-10.

Zadurska, Olga. "Popkulturowa Kariera Bohatera w Dresie. Rekonesans." In Literatura i Kultura Popularna Tom 19, edited by Anna Gemry, 113-25. Wrocław: Wydawnictwo Uniwersytetu Wrocławskiego, 2013.

Żakowski, Jacek. "Maria Peszek o swojej Najnowszej Płycie i Muzycznych Inspiracjach." Polityka, February 23, 2016. Accessed November 24, 2020. https://www.polityka.pl/tygodnikpolityka/kultura/1651466,1, maria-peszek-o-swojej-najnowszej= plycie-i-muzycznych-inspiracjach.read.

Zegler, Zbigniew. "Maria Peszek: Nie Jestem Kontrowersyjna." Polskie Radio Jedynka, July 15, 2013. Accessed November 23, 2020. https://www.polskieradio.pl/7/160/Artykul/888323, Maria-Peszeknie-jestem-kontrowersy.jna.

Zpav. "Platynowe Płyty CD: Archiwum." Bestsellery Zpav, November 7, 2012. Accessed November 23, 2020. http://bestsellery.zpav.pl/wyroznienia/platynoweplyty/cd/archiwum.php?year=2012\#title.

Zpav. "Platynowe Płyty CD: Archiwum." Bestsellery Zpav, November 16, 2016. Accessed November 23, 2020. http://bestsellery.zpav.pl/wyroznienia/platynoweplyty/cd/archiwum.php?year=2016\#title.

\section{Media Cited}

Maria Peszek. “Ludzie Psy / Official video / Maria Peszek.” YouTube video, 3:54. November 21, 2012. Accessed November 24, 2020. https://www.youtube.com/watch?v=sfYue0xuJ $\underline{\text { cI. }}$

Maria Peszek. “Ludzie Psy / Róbmy Klip / Maria Peszek." YouTube video, 3:41. January 18, 2013. Accessed November 24, 2020. https://www.youtube.com/watch?v=GRF5TrKqLOo.

Maria Peszek. “Maria Peszek - Ej Maria [Official Music Video].” YouTube video, 4:55. September 14, 2016. Accessed November 24, 2020. https://www.youtube.com/watch?v=84S6LzU2pRA.

Maria Peszek. "Maria Peszek - Modern Holocaust [Official Music Video].” YouTube video, 4:00. March 8, 2016. Accessed November 24, 2020. https://www.youtube.com/watch?v=atJrr2OdI9k.

Maria Peszek "Maria Peszek - Polska A B C i D [Official Lyric Video]." YouTube video, 4:07. January 26, 2016. Accessed November 24, 2020. https://www.youtube.com/watch?v=5CytySnKHrY. 
Peszek, Maria (@mariapeszek_official). “SORRY POLSKO 2020.” Instagram video, October 23, 2020. Accessed November 24, 2020. https://www.instagram.com/p/CGskQ $\underline{\text { dEJ }} \underline{1 \mathrm{~d} / \text {. }}$

Radio TOK FM. “Peszek o Piosence 'Modern Holocaust'." YouTube video, 11:43. March 17, 2016. Accessed November 23, 2020. https://www.youtube.com/watch?v=UhjdUGpPdSE.

Skokowska, Olga. “Strajk Kobiet." Spotify playlist, October 23, 2020. Last modified November 12, 2020. Accessed November 24, 2020.https://open.spotify.com/playlist/5Y8TXhPBkXcp6iVohFmy $\underline{\text { TD. }}$

VincentsGhost. "Pussy Riot, Punk Prayer." YouTube video, 1:52. July 29, 2012. Accessed November 24, 2020. https://www.youtube.com/watch?v=fW92sPezOMs\&t=46s.

\section{Biography}

Coming from Poland, Joanna Zienkiewicz is a Research Masters student in Arts, Media, and Literary Studies at the University of Groningen, Netherlands. Interested in researching the diverse themes of music, politics, participation, media, and identity, particularly in the Eastern European context, she graduated cum laude in 2019 with a Bachelor thesis on contemporary Eastern European protest songs. She has been a speaker of the IASPM Benelux Fourth Annual Student Research in Music Conference (Utrecht) and the 2019 International Interdisciplinary Conference on Art (Belgrade). In 2020, she published her first peer-reviewed article on transgression, dissimulation, and online culture wars in the Journal of Media and Culture $M / C$ and became affiliated with the Facta Ficta Research Centre located in Wrocław, Poland.

\section{Footnotes}

1. 
OLiS, “Oficjalna Lista Sprzedaży: Sales for the Period 01.10.2012-07.10.2012," OLiS, October 7, 2012, accessed November 23, 2020, http://olis.onyx.pl/listy/index.asp?idlisty=770\&lang=en;

Archiwum Listy Przebojów Trójki, “Notowanie 1609," LP3, November 30, 2012, accessed November 23, 2020, https://www.lp3.pl/notowanie/1609;

Maria Peszek, “Ludzie Psy / Official video / Maria Peszek,” YouTube, November 21, 2012, accessed November 23, 2020, https://www.youtube.com/watch?v=sfYue0xuJ $\underline{c}$.

2. Jan Bińczycki, “Siekiera, Motyka, Czarny Protest," Onet Kultura, November 30, 2016, accessed November 23, 2020, https://kultura.onet.pl/wiadomosci/siekiera-motyka-czarny-protest/2ygyn64. $\Xi$

3. Sie Kręci, "Maria Peszek Wystąpi po raz Pierwszy na Dużej Scenie Przystanku Woodstock," PolskieRadio24 Trójka, March 28, 2013, accessed November 23, 2020, https://www.polskieradio24.pl/9/1697/Artykul/811916,Maria-Peszek-wystapi-po-raz-pierwszy-naduzej-scenie-Przystanku-Woodstock.

4. Przemysław Gulda, "Maria Peszek- Stare Piosenki, Ważne Gesty,” Wyborcza, January 31, 2020, accessed November 23, 2020, https://trojmiasto.wyborcza.pl/troj) $\underline{\text { miasto/7, }}$ 35611,25648177, peszek-stare-piosenki-wazne-gesty.html.

5.

Peter Rutland, “The Pussy Riot Affair: Gender and National Identity in Putin's Russia," Nationalities Papers: The Journal of Nationalism and Ethnicity 42, no. 4 (2014): 579;

Marina Yusupova, "Pussy Riot: a Feminist Band Lost in History and Translation," Nationalities Papers: The Journal of Nationalism and Ethnicity 42, no. 4 (2014): 605.

6. Kim Mackrael and Bill Curry, "Pussy Riot Draws International Support after Guilty Verdict," The Globe and Mail, August 17, 2012, accessed November 23, 2020, https://www.theglobeandmail.com/news/world/pussy-riot-draws-international-support-afterguilty-verdict/article4487711/.

7. Beate Kutschke, "Political Music and Protest Song," in Protest Cultures: A Companion, ed. Kathrin Fahlenbrach, Martin Klimke, and Joachim Scharloth (New York and Oxford: Berghahn, 2016), 267. $\leftrightarrows$ 8. Ibid., 269-70.

9. Serge R. Denisoff, Sing a Song of Social Significance (Bowling Green: Bowling Green State University Popular Press, 1983), 60-61. 
10. Sumangala Damodaran, "Protest and Music," Oxford Research Encyclopedia of Politics, August 5, 2016, accessed November 23, 2020, https://oxfordre.com/politics/view/10.1093/acrefore/9780190228637.001.0001/acrefore9780190228637-e-81?result=2\&rskey=205QAq.

11. Serge R. Denisoff and Mark H. Levine, "The Popular Protest Song: The Case of 'Eve of Destruction'," Public Opinion Quarterly 35, no. 1 (1971): 118.

12.

Ron Eyerman and Andrew Jamison, Music and Social Movements: Mobilizing Traditions in the Twentieth Century (Cambridge: Cambridge University Press, 1998), 161;

Kutschke, "Political Music and Protest Song," 268. $ヒ$

13. Allan Moore, "Authenticity as Authentication," Popular Music 21, no. 2 (2002): 220.

14. Hans Weisethaunet and Ulf Lindberg, "Authenticity Revisited: The Rock Critic and the Changing Real," Popular Music and Society 33, no. 4 (2010): 465-485.

15.

Philip Auslander, "Framing Personae in Music Videos," in The Bloomsbury Handbook of Popular Music Video Analysis, ed. Lori A. Burns and Stan Hawkins (New York and London: Bloomsbury Academic, 2019), 95;

Philip Auslander, “On the Concept of Persona in Performance," Kunstlich 31, no. 3 (2015): $76 . \subseteq$ 16. Carol Vernallis, Unruly Media: YouTube, Music Video, and the New Digital Cinema (Oxford and New York: Oxford University Press, 2013), 232.

17.

Ibid., 212-30;

Carol Vernallis, “The Functions of Lyrics in Music Video," Journal of Popular Music Studies 14, no. 1 (2002): 11-31.

18. 
Andrew Goodwin, Dancing in the Distraction Factory: Music Television and Popular Culture (Minneapolis: University of Minnesota Press, 1992), 86;

Lori Burns, “Dynamic Multimodality in Extreme Metal Performance Video: Dark Tranquility's 'Uniformity,' Directed by Patric Ullaeus," in The Bloomsbury Handbook of Popular Music Video Analysis, ed. Lori A. Burns, and Stan Hawkins (New York and London: Bloomsbury Academic, 2019), 187;

Michael Chion, Audio-Vision: Sound on Screen (New York: Columbia University Press, 1994), $15 . \triangleq$

19.

Damodaran, "Protest and Music;"

Vernallis, "The Functions of Lyrics in Music Video," 28.

20. Homi K. Bhabha, Nation and Narration (London and New York: Routledge, 1990), 2-3.

21. Ibid., 1.

22. Homi K. Bhabha, The Location of Culture, 2nd ed. (London and New York: Routledge, 2004), 1.

23. Benedict Anderson, Imagined Communities: Reflections on the Origin and Spread of Nationalism (London: Verso, 2006), 6-7.

24. Ibid., 141.

25. Judith Butler, "Performative Acts and Gender Constitution: An Essay in Phenomenology and Feminist Theory," Theatre Journal 40, no. 4 (1988): 519-31. $\_$

26. Stuart Hall, quoted in Jennifer Daryl Slack, "The Theory and Method of Articulation in Cultural Studies," in Stuart Hall: Critical Dialogues in Cultural Studies, ed. David Morley and Kuan-Hsing Chen (London: Routledge, 1996), 116.

27. Vernallis, Unruly Media, $3 . \subseteq$

28.

Sergei Prozorov, "Pussy Riot and the Politics of Profanation: Parody, Performativity, Veridiction," Political Studies 62, no. 4 (2013): 766;

Gregory Gan, "Soaring to Dizzying Heights: Christ the Saviour Cathedral as a Historical Arena for the Persecution of Pussy Riot," Critique of Anthropology 35, no. 2 (2015): 178.

29. Prozorov, "Pussy Riot and the Politics of Profanation," 767. 
30. Rutland, "The Pussy Riot Affair," 577. $\leftrightarrows$

31. Yusupova, "Pussy Riot," 605.

32. Rutland, "The Pussy Riot Affair," 580.

33. Peter J. S. Duncan, “Contemporary Russian Identity between East and West," The Historical Journal 48, no. 1 (2005): $283 . \Leftarrow$

34. Ibid. $\doteq$

35. Ibid., 277-294.

36. Ibid., 283-94. $\subseteq$

37. Hubertus F. Jahn, “Us': Russians on Russianness," in National Identity in Russian Culture: An Introduction, ed. Simon Franklin and Emma Widdis, (Cambridge: Cambridge University Press, 2004), 53-73.

38. Anthony Cross, “Them': Russians on Foreigners," in National Identity in Russian Culture: An Introduction, ed. Simon Franklin and Emma Widdis, (Cambridge: Cambridge University Press, 2004), 74-92.

39.

Yusupova, "Pussy Riot," 607;

Colleen Walsh, "Stonewall Then and Now," The Harvard Gazette, June 27, 2019, accessed November 24, 2020, https://news.harvard.edu/gazette/story/2019/06/harvard-scholars-reflect-on-the-historyand-legacy-of-the-stonewall-riots $/ . \pm$

40.

Olga Issoupova, "From Duty to Pleasure?: Motherhood in Soviet and Post-Soviet Russia," in Gender, State and Society in Soviet and Post-Soviet Russia, ed. Sarah Ashwin, (London and New York:

Psychology Press, 2000), 30-54;

Marina Kiblitskaya, “Russia's Female Breadwinners: The Changing Subjective Experience," in Gender, State and Society in Soviet and Post-Soviet Russia, ed. Sarah Ashwin, (London and New York: Psychology Press, 2000), 55-70.

41. 
Janet E. Johnson and Aino Saarinen, “Twenty-First-Century Feminisms under Repression: Gender Regime Change and the Women's Crisis Center Movement in Russia," Signs 38, no. 3 (2013): 543-67; Oleg Riabov and Tatiana Riabova, "The Remasculinization of Russia?: Gender, Nationalism, and the Legitimation of Power Under Vladimir Putin," Problems of Post-Communism 61, no. 2 (2014): 23-25.Є 42. Sarah Ashwin, "Introduction: Gender State and Society in Soviet and Post-Soviet Russia," i Gender, State and Society in Soviet and Post-Soviet Russia, ed. Sarah Ashwin, (London and New York: Psychology Press, 2000), 21.

43. Tatiana Riabova and Oleg Riabov, "The Real Man of Politics in Russia (On Gender Discourse as a Resource for the Authority)," Social Sciences 42, no. 3 (2011): 67.

44. Yusupova, "Pussy Riot," $606 . \leftrightharpoons$

45. Prozorov, "Pussy Riot and the Politics of Profanation," 767.

46. Gan, "Soaring to Dizzying Heights," 179.

47.

Duncan, “Contemporary Russian Identity,” 283;

Gan, "Soaring to Dizzying Heights," 166-186.

48. Ibid., 179. $ヒ$

49. Goodwin, Dancing in the Distraction Factory, $86 . \Leftarrow$

50. Prozorov, "Pussy Riot and the Politics of Profanation," 766.

51. Rutland, "The Pussy Riot Affair," 580.

52. Prozorov, "Pussy Riot and the Politics of Profanation," 770.

53. Goodwin, Dancing in the Distraction Factory, 86. $\uplus$

54. Denisoff, "Sing a Song of Social Significance," $6 . \sqcup$

55. Ibid., 60.

56. Yves Nicholas Vanderhaeghen, "Other than Ourselves: an Exploration of 'Self-Othering' in Afrikaner Identity Construction in Beeld Newspaper," (PhD diss., University of KwaZulu-Natal, 2014), 30. 
57.

Olu Jenzen, “The Queer Uncanny," eSharp 9, no. 1 (2007): 6;

Lauren Ashwell, "Gendered Slurs," Social Theory and Practice 42, no. 2 (2016): 228-39;

Kutschke, "Political Music and Protest Song," 265.

58. Weisethaunet and Lindberg, "Authenticity Revisited," 472.

59. Denisoff, Sing a Song of Social Significance, $60 . \Xi$

60. Denisoff and Levine, "The Popular Protest Song," 118. $\boxminus$

61. Rutland, “The Pussy Riot Affair," 580.

62. Ibid., 581.

63. Moore, "Authenticity as Authentication," 220.

64. Rutland, “The Pussy Riot Affair," 581.

65. Riabova and Riabov, "The Real Man of Politics in Russia," 67.

66. Prozorov, "Pussy Riot and the Politics of Profanation," 767.

67. Culture.pl, “Maria Peszek," Culture.pl, November 1, 2014, accessed November 23, 2020, https://culture.pl/en/artist/maria-peszek.

68.

OLiS, “Oficjalna Lista Sprzedaży: Sales for the Period 01.10.2012-07.10.2012"; OLiS, “Oficjalna Lista Sprzedaży: Sales for the Period 26.02.2016-03.03.2016," OLiS, March 3, 2016, accessed November 23, 2020, http://olis.onyx.pl/listy/index.asp?idlisty=1010\&lang=en;

Radio TOK FM, “Peszek o Piosence 'Modern Holocaust'," YouTube, March 17, 2016, accessed

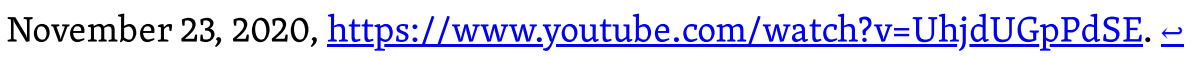

69.

Zpav, "Platynowe Płyty CD: Archiwum," Bestsellery Zpav, November 7, 2012, accessed November 23, 2020, http://bestsellery.zpav.pl/wyroznienia/platynoweplyty/cd/archiwum.php?year=2012\#title;

Zpav, "Platynowe Płyty CD: Archiwum," Bestsellery Zpav, November 16, 2016, accessed November 23, 2020, http://bestsellery.zpav.pl/wyroznienia/platynoweplyty/cd/archiwum.php?year=2016\#title.. 
70. Zbigniew Brzezinski, The Soviet Bloc, Unity and Conflict (Cambridge: Harvard University Press, 1967). $\doteq$

71. Helena Chmielewska-Szlajfer, Reshaping Poland's Community after Communism: Ordinary

Celebrations (Warsaw: Palgrave Macmillan, 2019), $5 . \leftrightharpoons$

72.

Richard Middleton, Studying Popular Music (Milton Kenyes and Philadelphia: Open University Press, 1990), 173;

Krzysztof Garczewski and Anna Garczewska, "Sounds of the Opposition - Music and Politics in Poland 1970-1989," Confrontation and Cooperation: 1000 Years of Polish-German-Russian Relations: The Journal of Kolegium Jagiellonskie Torunska Szkola Wyzsza 1, no. 1 (2014): 45-55.

73. Chmielewska-Szlajfer, Reshaping Poland's Community after Communism.

74. Ibid., $2 . \doteq$

75. Ibid., 6. $\subseteq$

76.

Ibid., 137-141;

Derek Scally, "Polish National Broadcaster Turns into Propaganda Machine," The Irish Times, May 19, 2016, accessed November 23, 2020, https://www.irishtimes.com/news/world/europe/polishnational-broadcaster-turns-into-propaganda-machine-1.2652527.

77. Dawid Bunikowski, “The Constitutional Crisis in Poland, Schmittian Questions, and Kaczyński's Political and Legal Philosophy," Journal of Contemporary European Studies 26, no. 3 (2018): 285-307. 78. Chmielewska-Szlajfer, Reshaping Poland's Community after Communism, 33. 79. Susan Gal Gail Kligman, Reproducing Gender: Politics, Publics, and Everyday Life after Socialism (Princeton: Princeton University Press, 2000).$\bullet$

80. Ann Snitow and Katheryn Detwiler, "Gender Trouble in Poland," Dissent Magazine, Fall 2016, https://www.dissentmagazine.org/article/gender-trouble-poland-pis-abortion-ban.. 81. 
P.Mal, “Andrzej Duda o LGBT: Próbują Wmówić, że to Ludzie. To Ideologia,” Rzeczpospolita, June 13, 2020, accessed November 23, 2020, https://www.rp.pl/Wybory-prezydenckie-2020/200619782Andrzej-Duda-o-LGBT-Probuja-wmowic-ze-to-ludzie-To-ideologia.html;

Emma Powys Maurice, "A Third of Poland has now been Declared an 'LGBT-Free Zone', Making Intolerance Official," Pink News, February 25, 2020, accessed November 23, 2020, https://www.pinknews.co.uk/2020/02/25/third-of-poland-lgbt-free-zone-atlas-of-hatehomophobia/?fbclid=IwAR2TK6aa 9AA7k7mR608dtIiONBknCQgdjcmgRe1KBRrf2aP0xDFK52fjTc. 82. Snitow and Detwiler, "Gender Trouble in Poland."

83. Thalia Beathy, “Strike to Win: Can Polish Feminists Turn Protest Into Power?," Dissent Magazine, Summer 2017, https://www.dissentmagazine.org/article/poland-feminists-strike-manifa$\underline{\text { razem-protest-power. }}$.

84.

Marta K. Nowak, “Bunt Kobiet Silniejszy niż Izolacja. Rusza Ogólnopolski Protest przeciwko Zakazowi Aborcji," OKO.Press, April 11, 2020, accessed November 23, 2020, https://oko.press/buntkobiet-silniejszy-niz-izolacja-rusza-ogolnopolski-protest-przeciwko-zakazowi-aborcji/;

Antonia Mortensen and Laura Smith-Spark, "Poland's Biggest Protests in Decades Stand against Abortion Ban," CNN, October 31, 2020, accessed November 24, 2020, https://edition.cnn.com/2020/10/31/europe/poland-abortion-protests-scli-intl/index.html. $\doteq$ 85. DSM, “'Strajk Kobiet’, ‘*******’ i ‘Moje ciało, mój wybór’. Przez Lublin przeszedł kolejny protest przeciwników decyzji Trybunału [GALERIA]," Lubin24.pl, October 24, 2020, accessed November 24, 2020, https://www.lublin24.pl/wiadomosci/strajk-kobiet-i-moje-cialo-moj-wybor-przez-lublinprzeszedl-kolejny_protest-przeciwnikow-decyzji-trybunalu-galeria/Xh805d93koiJt61UhggE. 86. Marta Strzelecka, "Maria Peszek - Pełny Wywiad. 'Trudno jest być innym'," Wprost, October 4, 2012, accessed November 23, 2020, https://www.wprost.pl/tylko-u-nas/350964/Maria-Peszekpelny-wywiad-Trudno-jest-byc-innym.html. $\triangleq$

87. Zbigniew Zegler, “Maria Peszek: Nie Jestem Kontrowersyjna," Polskie Radio Jedynka, July 15, 2013, accessed November 23, 2020, https://www.polskieradio.pl/7/160/Artykul/888323, Maria-Peszeknie-jestem-kontrowersy.j. $\underline{\text { na. }}$.

88. 
Zpav, "Platynowe Płyty CD: Archiwum”;

Archiwum Listy Przebojów Trójki, "Notowanie 1609”;

Archiwum Listy Przebojów Trójki, “Notowanie 1622."

89. Marta Strzelecka, “Maria Peszek: Można z tego Piekła Wrócić,” Wprost, September 30, 2012, accessed November 23, 2020, https://www.wprost.pl/tylko-u-nas/350196/maria-peszek-mozna-ztego-piekla-wrocic.html. $\subseteq$

90. Cristina Demaria, "The Performative Body of Marina Abramović: Rerelating (in) Time and Space," European Journal of Women's Studies 11, no. 3 (2004): 295-307.

91.

Vernallis, "Music Video's Second Aesthetic?," 225;

Burns, “Dynamic Multimodality,” 187.

92. Chion, Audio-Vision, $15 . \subseteq$

93. Wojciech Przylipiak, "Maria Peszek: Chciałam Skupić się na Nienawiści, ale Wyszła Płyta o Wolności [WYWIAD]," Dziennik.pl, February 26, 2016, accessed November 23, 2020, https://muzyka.dziennik.pl/news/artykuly/514147, maria-peszek-wywiad-nowa-plyta-karabinpolska-a-b-c-i-d.html.

94. Middleton, Studying Popular Music, 173.

95. Burns, "Dynamic Multimodality," 187.

96. Vernallis, “The Functions of Lyrics in Music Video," 28.

97. Przylipiak, “Maria Peszek."

98. Ibid. $\triangleq$

99.

Zpav, "Platynowe Płyty CD: Archiwum";

Archiwum Listy Przebojów Trójki, “Notowanie 1781," LP3, March 18, 2016, accessed November 23, 2020, https://www.lp3.pl/notowanie/1781.

100. I-D Staff, "ITunes Ocenzurował Marię Peszek," I-D Vice, February 23, 2016, accessed November 23, 2020, https://i-d.vice.com/pl/article/bj) $\underline{\text { md53/itunes-ocenzurowal-marie-peszek. }}$. 
101. Przemysław Bollin, "Maria Peszek: Holocaust Nigdy się nie Skończył [Wywiad]," Onet Muzyka, February 26, 2016, accessed November 23, 2020, https://kultura.onet.pl/muzyka/wywiady-iartykuly/maria-peszek-holocaust-nigdy-sie-nie-skonczyl-wywiad/bnh443w.

102. Jacek Jarocki, “Maria Peszek- Karabin,” Muzyczny Horyzont, September 2, 2017, accessed November 23, 2020, http://www.muzycznyhoryzont.pl/maria-peszek-karabin/. 103. Przylipiak, "Maria Peszek."

104. Bhabha, Nation and Narration, 1; Chmielewska-Szlajfer, Reshaping Poland's Community after Communism, 33.

105. Maria Peszek, "Maria Peszek - Modern Holocaust [Official Music Video]," March 8, 2016, accessed November 24, 2020, https://www.youtube.com/watch?v=atJ $\underline{\operatorname{rr} 20 d I 9 k} . \pm$ 106. Vernallis, "The Functions of Lyrics in Music Video," 17. 107. Jś, “Maria Peszek Wróciła i Nadal nie Lubi Kościoła. Posłuchaj Piosenki Polska A B C i D," Wyborcza, January 26, 2016, accessed November 23, 2020, https://wyborcza.pl/1, $\underline{75410}, \underline{19539375}$, maria-peszek-wrocila-i-nadal-nie-lubi-kosciola-posluchajpiosenki.html. $\bullet$

108. Ibid. $\subseteq$

109. Yusupova, "Pussy Riot," $604 . \subseteq$

110. Vincentee9 (@Vincentee9), 2016, comment on Maria Peszek, “Maria Peszek - Polska A B C i D.”

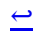

111. Maria Peszek, "Maria Peszek - Ej Maria [Official Music Video]," September 14, 2016, accessed November 24, 2020, https://www.youtube.com/watch?v=84S6LzU2pRA.

112. Stasia Wąs, "Maria Peszek jest Dresiarzem!," I-D Vice, September 15, 2016, accessed November 24, 2020, https://i-d.vice.com/pl/article/zm4wya/maria-peszek-jest-dresiarzem. 113. 
Renata Pasternak-Mazur, “The Black Muse: Polish Hip-Hop as the Voice of "New Others" in the PostSocialist Transition." Music \& Politics 3, no.1

(2009), https://quod.lib.umich.edu/m/mp/9460447.0003.103/--black-muse-polish-hip-hop-as-thevoice-of-new-others?rgn=main; view=fulltext;

Olga Zadurska, "Popkulturowa Kariera Bohatera w Dresie. Rekonesans," in Literatura i Kultura Popularna Tom 19, ed. Anna Gemry (Wrocław: Wydawnictwo Uniwersytetu Wrocławskiego, 2013), 113-125;

Tomasz Broda, “Pejzaż z Narodowcem, czyli Horror i Ojczyzna,” Tygodnik Wrocław Wyborcza, November 13, 2015, accessed November 24, 2020, https://wroclaw.wyborcza.pl/wroclaw/1,142076,19181701,pejzaz-z-narodowcem-czyli-horror-iojczyzna-rysunki-brody.html.

114. Jenzen, "The Queer Uncanny," 6.

115. Maria Peszek, "Maria Peszek - Ej Maria [Official Music Video]," September 14, 2016, accessed November 24, 2020, https://www.youtube.com/watch?v=84S6LzU2pRA.

116. Denisoff and Levine, "The Popular Protest Song," 118.

117.

Wojciech Miodoński, 2015;

Ezrael, 2018;

Radosław Ostrowski, 2014, comments on Peszek, "Ludzie Psy." 118.

Alicja Olejnik, 2016;

Natalia Mikurda, 2017;

For praise, see Karolina Hilger, 2015, comments on Peszek, "Ludzie Psy." 119.

Anja Ch, 2016;

Natalia Mikurda, 2017;

Daniel Duda, 2016;

Artur Kacała, 2014, comments on Peszek, "Ludzie Psy.” 
120.

For personal stories, see blalbllaah dopwkdow, 2019;

Vamps, 2018;

For "hit home," see Paulka !, 2017, comments on Peszek, "Ludzie Psy." 121. Dominika, 2017, comment on Peszek, "Ludzie Psy."

122.

beeesful, 2016;

Julia Kurszewska, 2015, comments on Peszek, “Ludzie Psy.”

123.

$\mathrm{Pa} \mathrm{Pa}, 2019$;

Vidar Rimini, 2018;

Aga Zgaga, 2017;

Jowita Białobrzeska, 2020, comments on Peszek, "Ludzie Psy."

124.

elCactusR, 2020;

One Man Army, 2017;

Polish Lass, 2018;

MILU, 2018, comments on Peszek, "Ludzie Psy."

125. Roch syn Mieczysława, 2018, comment on Peszek, "Ludzie Psy."

126.

Jan Kowalski, 2015;

Piotr Kuźmiński, 2016;

Agata Zegis, 2017, Peszek, “Ludzie Psy.”

127. 
Aleksandra Dybiec, “'Bluźnierczy i Antypolski'. Senator PiS o Koncercie Marii Peszek," Wyborcza Płock, September 4, 2013, accessed November 24,

2020, http://plock.wyborcza.pl/plock/1,35681,14549818,_Bluznierczy_i antypolski Senator PiS o koncercie.

$\underline{\text { html; }}$

Wojciech Cieśla, “PiS: First we Take Podlasie,” Newsweek Polska, July 24, 2013, accessed November 24, 2020, https://www.newsweek.pl/polska/pis-first-we-take-podlasie-newsweekpl/vnrgltz. 128. Jarzenica, 2016; V'yell Gohl, 2016, accessed November 24, 2020, comments on Peszek, "Modern Holocaust." $\triangleq$

129.

For depicting Polish reality, see Monika Pikulik, 2016;

For "only proven even more by the hateful comments," see Michal Miksa, 2016, comments on Peszek, "Modern Holocaust."

130. Ciechan, 2016, comment on Peszek, "Modern Holocaust." 131.

Jacek Żakowski, “Maria Peszek o swojej Najnowszej Płycie i Muzycznych Inspiracjach,” Polityka, February 23, 2016, accessed November 24,

2020, https://www.polityka.pl/tygodnikpolityka/kultura/1651466,1, maria-peszek-o-swojej= najnowszej=plycie-i-muzycznych-inspiracjach.read;

burtonisreligion, 2016;

MrEmar26, 2016;

olseneudezet1, 2016, comments on Peszek, “Modern Holocaust." 132.

Mela Nowacka, 2020;

Hella Agnes, 2020;

Niko Bartkiewicz, 2020;

Adam Boch, 2019;

znakomicie nie jest, 2019, comments on Peszek, "Modern Holocaust." 
133.

Madzia 1905, 2020;

Brail, 2020;

Niko Bartkiewicz, 2020, comments on Peszek, "Modern Holocaust."

134. KristVladic, 2016, comment on Peszek, "Polska A B C i D."

135.

KristVladic, 2016, accessed November 24, 2020, comment on Peszek, "Polska A B C i D";

Jś, "Maria Peszek Wróciła." $\leftrightarrows$

136.

For truthfulness, authenticity, and relevance, see Paweł Kuś, 2019;

ryzykownie, 2020;

Daniel, 2019;

For "predicted the future," see Frederica M.B., 2019, comment on Peszek, "Polska A B C i D." 137.

For “rainbows," see Michał, 2016;

For “right-wing views," see MegaKoks1 1, 2017, comments on Peszek, "Polska A B C i D." 138.

Kem Pol, 2016;

For disagreeing with rhetoric, see RedCarpetMikil, 2016;

Set and Setting, 2017, comments on Peszek, "Polska A B C i D."

139.

For supporting pacifist message, see Vincentee9, 2016;

Yenchey, 2016;

Set and Setting, 2017;

for participation, see Grzegorz Nowak, 2019;

mt2 Trólka, 2016, comments on Peszek, “Polska A B C i D.” 
140. Piotr Kopacz, 2020, comment on Peszek, "Polska A B C i D."

141.

MrHotFlorida, 2018;

km8585, 2017;

Leo K, 2018;

To Ja, 2019, comments on Peszek, "Polska A B C i D."

142.

agatek, 2020;

For praising acting skill, see Magdalena Ka, 2017;

Mellon, 2017;

For breaking industry conventions, see Ida, 2017;

Twoja Stara, 2018;

For provokcation, see varvor22, 2017, comments on Peszek, “Ej Maria.”

143.

welz, 2020;

Dominika Karcz, 2020, comments on Peszek, “Ej Maria.”

144.

Jarek Z, 2017;

Greta Grey, 2018, comments on Peszek, “Ej Maria.”

145.

Polish Feminists (@PolishFeminists), “Nasz Ulubiony Plakat z Warszawskiej \#Manifa,” Twitter post, March 5, 2019, accessed November 23, 2020, https://twitter.com/i/web/status/1102905181921034240;

Bińczycki, “Siekiera, Motyka, Czarny Protest”;

Agata Puścikowska, “Byłam na Manifie,” Gość.pl Warszawski, March 10, 2013, accessed November 24, 2020, https://warszawa.gosc.pl/doc/1481241.Bylam-na-Manifie/4. 146. 
DSM, “'Strajk Kobiet'.”

Olga Skokowska, “Strajk Kobiet," Spotify playlist, October 23, 2020, accessed November 24, 2020, https://open.spotify.com/playlist/5Y8TXhPBkXcp6iVohFmyTD.․․

147. Maria Peszek, "DZISIAJ! \#wyboryprezydenckie2020 \#future \#przyszłość \#polska," Facebook, June 28, 2020, accessed November 24, 2020,

https://www.facebook.com/peszekmaria/photos/a.455421470201/10158203076930202/.

148. Rutland, "The Pussy Riot Affair," 581. $ヒ$

149. Ibid., 579.

150. Ibid., 291-314.

151. Nicholas Tochka, "Cosmopolitan Inscriptions?: Mimicry, Rap, and Rurbanity in Post-Socialist Albania," in Hip Hop at Europe's Edge: Music, Agency, and Social Change, ed. Milosz Miszczynski and Adriana Helbig, (Bloomington and Indianapolis: Indiana University Press, 2017), 165-181. 